\title{
Cortical Adenylyl Cyclase 1 Is Required for Thalamocortical Synapse Maturation and Aspects of Layer IV Barrel Development
}

\author{
Takuji Iwasato, ${ }^{1,2 \star}$ Melis Inan, ${ }^{3,4 *}$ Hiroaki Kanki, ${ }^{1}$ Reha S. Erzurumlu, ${ }^{5}$ Shigeyoshi Itohara, ${ }^{1}$ and Michael C. Crair ${ }^{3,4}$ \\ ${ }^{1}$ Laboratory for Behavioral Genetics, RIKEN Brain Science Institute, Saitama 351-0198, Japan, ${ }^{2}$ PRESTO, Japan Science and Technology Agency, Saitama \\ 332-0012, Japan, ${ }^{3}$ Department of Neurobiology, Yale University School of Medicine, New Haven, Connecticut 06510, ${ }^{4}$ Program in Developmental Biology, \\ Baylor College of Medicine, Houston, Texas 77030, and 5Department of Anatomy and Neurobiology, University of Maryland, Baltimore, School of Medicine, \\ Baltimore, Maryland 21201
}

Experimental evidence from mutant or genetically altered mice indicates that the formation of barrels and the proper maturation of thalamocortical (TC) synapses in the primary somatosensory (barrel) cortex depend on mechanisms mediated by neural activity. Type 1 adenylyl cyclase (AC1), which catalyzes the formation of cAMP, is stimulated by increases in intracellular $\mathrm{Ca}^{2+}$ levels in an activitydependent manner. The AC1 mutant mouse, barrelless ( $b r l)$, lacks typical barrel cytoarchitecture, and displays presynaptic and postsynaptic functional defects at TC synapses. However, because AC1 is expressed throughout the trigeminal pathway, the barrel cortex phenotype of $b r l$ mice may be a consequence of $\mathrm{ACl}$ disruption in cortical or subcortical regions. To examine the role of cortical $\mathrm{ACl}$ in the development of morphological barrels and TC synapses, we generated cortex-specific AC1 knock-out (CxAC1KO) mice. We found that neurons in layer IV form grossly normal barrels and TC axons fill barrel hollows in $\mathrm{CxAC1KO}$ mice. In addition, whisker lesion-induced critical period plasticity was not impaired in these mice. However, we found quantitative reductions in the quality of cortical barrel cytoarchitecture and dendritic asymmetry of layer IV barrel neurons in CxAC1KO mice. Electrophysiologically, CxAC1KO mice have deficits in the postsynaptic but not in the presynaptic maturation of TC synapses. These results suggest that activity-dependent postsynaptic AC1- cAMP signaling is required for functional maturation of TC synapses and the development of normal barrel cortex cytoarchitecture. They also suggest that the formation of the gross morphological features of barrels is independent of postsynaptic AC1 in the barrel cortex.

Key words: somatosensory cortex; activity dependent; AC1; barrel; thalamocortical; conditional knock-out

\section{Introduction}

Since the discovery of "barrels" in 1970 (Woolsey and Van der Loos, 1970), the somatosensory (barrel) cortex of rodents has emerged as a useful model system to examine the mechanism underlying development of complex neural circuits typical of the mammalian brain. In rodents, the pattern of facial whiskers on the snout is recapitulated throughout the ascending trigeminal pathway in the form of "barellettes" in the brainstem, "barre-

Received Feb. 24, 2008; revised April 7, 2008; accepted April 27, 2008.

This work was supported in part by a Grant-in-Aid for Scientific Research on Priority Areas (Elucidation of Neural Network Function in the Brain) from the Ministry of Education, Culture, Sports, Science, and Technology, Japan (T.I.); National Institutes of Health Grant R01 MH62639; and the Rett Syndrome Research Foundation (M.C.C.). We thank Reiko Ando, Mizuho Iwama, and Yoshikazu M. Saito for technical assistance, Brain Science Institute Research Resources Center for animal care and technical assistance, Akash Datwani for the Golgi protocol, Jun-ichi Miyazaki for CAG-CAT-Z mice, Yueyi Zhang for technical assistance, and members of the Crair Laboratory for helpful comments on this manuscript.

*T.I. and M.I. contributed equally to this work.

Correspondence should be addressed to either of the following: Shigeyoshi Itohara, Laboratory for Behavioral Genetics, RIKEN Brain Science Institute, 2-1 Hirosawa, Wako-shi, Saitama 351-0198, Japan, E-mail: sitohara@brain.riken.jp; or Michael C. Crair, Department of Neurobiology, Yale University School of Medicine, 333 Cedar Street, SHM B301, New Haven, CT 06510, E-mail: michael.crai@@yale.edu.

DOI:10.1523/JNEUROSCI.0815-08.2008

Copyright $\odot 2008$ Society for Neuroscience $\quad$ 0270-6474/08/285931-13\$15.00/0 loids" in the ventrobasal (VB) thalamus, and "barrels" in layer IV of the somatosensory cortex. Each mature cortical barrel is composed of a barrel wall and a barrel hollow. During the first postnatal week of development, thalamocortical (TC) axons cluster within the barrel hollow, whereas layer IV neurons arrange their cell bodies to form the barrel wall and acquire an asymmetric morphology by preferentially orienting their dendrites toward the barrel hollow to synapse with TC axons.

Maturation of TC synapses takes place early in postnatal life, when barrels are just forming. One of the proposed mechanisms for synapse maturation during map formation is by Hebbianbased synaptic plasticity mechanisms, such as long-term potentiation (LTP), which is thought to selectively strengthen topographically appropriate synapses through the addition of AMPA receptors at the postsynaptic density (Malinow and Malenka, 2002). Consistent with this model, LTP can be reliably induced at immature TC synapses, and the ratio of AMPA to NMDA receptor-mediated currents (AMPA/NMDA ratio) increase with age (Crair and Malenka, 1995).

Barrelless ( $b r l)$ mice, a spontaneous mutant mouse line that lacks a barrel map, have a mutation in the adenylyl cyclase 1 (adcyl or AC1) gene (Welker et al., 1996; Abdel-Majid et al., 
1998). AC1 is one of two adenylyl cyclases that are activated by increases in $\mathrm{Ca}^{2+}$ (Wang and Storm, 2003), which at dendritic spines takes place mostly by stimulation of NMDA receptors during neuronal activity (Kovalchuk et al., 2000). AC1 activation leads to an increase in cAMP production, a second messenger whose primary target is cAMP-dependent protein kinase (PKA). In addition to $b r l$ mice, knock-out (KO) mice that lack NMDA receptor function only in cortical excitatory neurons $(\mathrm{CX}-$ $\mathrm{NR} 1 \mathrm{KO}$ mice) and $\mathrm{KO}$ mice that lack the type II $\beta$ regulatory subunit of PKA (PKARII $\beta$ KO mice) have barrel map defects (Iwasato et al., 2000; Inan et al., 2006; Watson et al., 2006). These reports suggest that the function of signaling molecules immediately upstream and downstream of AC1 activation is necessary for barrel map formation.

Both $b r l$ and PKARII $\beta$ KO mice have postsynaptic deficits at TC synapses in which LTP induction and the developmental increase in AMPA receptor response at TC synapses are impaired (Lu et al., 2003; Inan et al., 2006). Presynaptic defects are also found at $b r l$ TC synapses in which neurotransmitter release efficacy is reduced (Lu et al., 2006). Together, this evidence suggests that barrel map formation relies on proper TC synaptic maturation and that the AC1-PKA signaling pathway regulates the structural and functional maturation of the barrel cortex layer IV neurons. However, because AC1 is present throughout the trigeminal pathway during early postnatal development (Matsuoka et al., 1997; Nicol et al., 2005), it remains unclear whether lack of cortical AC1, subcortical AC1, or both is the source of the defects observed in $b r l$ mice.

To investigate the role of cortical AC1 in the development of barrel cytoarchitecture and the functional maturation of TC synapses, we generated cortex-specific $\mathrm{KO}$ mice in which $\mathrm{ACl}$ is absent in cortical excitatory neurons $(\mathrm{CxAC1KO})$ but not in any subcortical somatosensory centers. We found that the loss of AC1 in layer IV neurons is sufficient to reproduce the postsynaptic, but not presynaptic, electrophysiological deficits observed in $\mathrm{brl}$ TC synapses. Morphologically, while grossly normal barrels are formed, layer IV neurons display reduced dendritic asymmetry in CxAC1KOs compared with controls and layer IV neuron barrel cytoarchitecture is degraded in $\mathrm{CxAC} 1 \mathrm{KO}$ mice. Thus, cortical $\mathrm{AC} 1$ has specific roles in the functional and morphological maturation of barrel cortex layer IV.

\section{Materials and Methods}

Animals. Emx1-Cre (knock-in $\Delta \mathrm{Neo}, \mathrm{K} \Delta \mathrm{N}$ ) mice in which the pgk-neo selection marker gene had been deleted from the locus have been described previously (Iwasato et al., 2004). The AC1-flox allele, in which $\mathrm{AC} 1$ exon 1 containing transcriptional and translational initiation sites was flanked by a pair of loxPs, was generated by using homologous recombination in E14 embryonic stem cells and deleting a pgk-neo by flp/FRT recombination. AC1-null allele was generated by expressing Cre recombinase in germline of AC1-flox mice. CxAC1KO (Emx-Cre; $\mathrm{ACl}^{\text {flox/- }}$ ) and control (Emx-Cre; $\mathrm{ACl}^{+/-}, \mathrm{ACl}^{\text {flox/- }}, \mathrm{ACl}^{\text {flox/+ }}$, and $\mathrm{ACl}^{+/-}$) mice were obtained by crossing Emx1-Cre; $\mathrm{AC1}^{-1-}$ or Emx1Cre; $\mathrm{AC}^{+/-}$male and $\mathrm{AC} 1^{\text {flox/flox }}$ or $\mathrm{AC} 1^{\text {flox/+ }}$ females. In a few histological analyses, Emx1-Cre Tg3 mice (Iwasato et al., 2004) were also used to generate $\mathrm{CxAC1KO}$. In both Emx1-Cre $\mathrm{K} \Delta \mathrm{N}$ and Emx1-Cre Tg3 mice, Cre-mediated recombination is restricted to the dorsal telencephalon (Iwasato et al., 2004). All physiological experiments and the majority of histological experiments were performed using mice backcrossed onto C57BL/6 genetic background more than eight generations.

Mice were genotyped by PCR with the AC1-WND primers ( $5^{\prime}$-CAT GCC CTC TTG GGT ACT GTC TGT C-3' 5' $^{\prime}$-CTC CCT TCA GAC CCT GTC ACC TCT G-3' ${ }^{\prime} 5^{\prime}$-CTT GGG TAC TGT CTG TCT AGC CAT C-3', and 5'-AGG GAC CAA GAT CTG GCC TCT CAT C-3': 277, 157, and $111 \mathrm{bp}$ for flox, null, and wild-type alleles, respectively) and Cre primers
(Iwasato et al., 2004). Primers for the NR1 gene (Iwasato et al., 1997) or IL2 gene (5'-CTAGGCCACAGAATTGAAAGATCT-3', 5'-GTAGGTGGAAATTCTAGCATCATCC-3') were run together with Cre primers as a positive control. PCR products were resolved on a $2-3 \%$ agarose gel and detected with ethidium bromide.

The experimental procedures and housing conditions for animals were approved by the institutes' Animal Experimental Committees and all animals were cared for and treated humanely in accordance with the institutional Guidelines for Experiments Using Animals.

Reverse transcriptase-PCR. Quantitative reverse transcriptase-PCR (qRT-PCR) was performed as described previously (Iwasato et al., 2007). In brief, total RNAs were isolated from the barrel cortex of CxAC1KO $(n=4)$ and $\mathrm{ACl}^{\text {flox } /-}(n=5)$ mice at postnatal day 3 (P3) and $\mathrm{CxAC} 1 \mathrm{KO}(n=4)$ and $\mathrm{AC}^{\text {flox } /-}(n=4)$ mice at P7 using RNeasy Mini kit (Qiagen). All samples were digested on-column with RNase-free DNase. cDNA was synthesized from total RNA using Superscript III two-step qRT-PCR kit (Invitrogen). Real-time qPCR was performed using Platinum SYBR green qRT-PCR Super mix UDG with ROX (Invitrogen) by ABI Prism 7700 (ABI). The PCR conditions were $50^{\circ} \mathrm{C}$ for $2 \mathrm{~min}$, $95^{\circ} \mathrm{C}$ for $2 \mathrm{~min}, 45 \mathrm{cycles}$ of $95^{\circ} \mathrm{C}$ for $15 \mathrm{~s}, 60^{\circ} \mathrm{C}$ for $30 \mathrm{~s}$, and $72^{\circ} \mathrm{C}$ for $30 \mathrm{~s}$. At the end of each program, a melt-curve analysis was performed. All qRT-PCR were performed in triplicate for each cDNA sample. The primer set used was $5^{\prime}$-ccttttggtcaccttcgtgt-3' and 5' gctgtgaccagtaagtgcga-3'. Diluted linearized plasmid pS18 (for AC1 exon1 genomic DNA) was used as a standard for absolute cDNA quantification.

cDNA samples were prepared from brain total RNA derived from two each of 6-month-old $\mathrm{AC} 1^{\text {flox/flox }}$ mice and $\mathrm{AC} 1^{\Delta / \Delta}$ mice using Superscript II RT (Invitrogen) and oligo-dT primers. PCRs were performed using forward primers (f1, 5' -CCC TGC TCT TCT TTG GTG TG-3'; f2, $5^{\prime}$-GGT TGC TCA TGA GCC TCA TG- ${ }^{\prime}$ ) and reverse primers ( 4 4, GTT CCT CTC ATG GCC ATG AC; r9, 5'-ATG ACA TTG GCC AGG GTC AC-3'). The PCR conditions were $94^{\circ} \mathrm{C}$ for $2 \mathrm{~min}, 30$ cycles of $94^{\circ} \mathrm{C}$ for $30 \mathrm{~s}, 60^{\circ} \mathrm{C}$ for $30 \mathrm{~s}$, and $72^{\circ} \mathrm{C}$ for $1 \mathrm{~min}$, and $72^{\circ} \mathrm{C}$ for $7 \mathrm{~min}$.

In situ hybridization. Using PCR primers (5'-CTTTTCCTGGCGCTGTTCGTG-3' and 5'-TGTGACCAGTAAGTGCGAGG-3'), a 297 bp fragment within AC1 exon1 was amplified from pS27 cone derived from genomic DNA of 129 strain. This PCR product was purified by electrophoresis and QIAquick Gel Extraction kit (Qiagen) and subcloned into pGEM-T Easy vector (Promega) to generate the pS60 clone. The pS60 clone verified by nucleotide sequencing was used as a template to generate the antisense probe using the Riboprobe System-SP6 (Promega). In situ hybridization was done as described previously (Iwasato et al., 1997, 2000) with minor modifications. Briefly, frozen brains were cut at a thickness of $12 \mu \mathrm{m}$ in the sagittal or coronal planes on a cryostat. Sections were postfixed in $4 \%$ paraformaldehyde (PFA) in PBS, pH 7.2, before pretreatment. Hybridization was done at $58^{\circ} \mathrm{C}$ for $18 \mathrm{~h}$ in hybridization buffer with a ${ }^{33} \mathrm{P}$-labeled RNA probe. Sections were washed in a series of SSC buffers of increasing stringency after RNaseA treatment. The final wash was done in $0.1 \times$ SSC at $60^{\circ} \mathrm{C}$ for $30 \mathrm{~min}$. The sections were exposed to $\beta$-max film (GE Healthcare) for $9-12 \mathrm{~d}$ and dipped in NTB3 emulsion (Kodak) followed by exposure for $>1$ month. After development, sections were stained with cresyl violet. Expression patterns and levels were ensured by two sets of reactions using three each of $\mathrm{CxAC1KO}$ and $\mathrm{ACl}^{\text {flox/- }}$ mice at $\mathrm{P} 7$ and two each of $\mathrm{CxAC} 1 \mathrm{KO}$ and $\mathrm{AC} 1^{\text {flox } /-}$ mice at $\mathrm{P} 1$. Brains of $\mathrm{AC} 1^{-1-}$ mice at $\mathrm{P} 1$ and $\mathrm{P} 7$ were used as negative controls.

Cytochrome oxidase staining. Barrel cortex was removed following the methods described by Strominger and Woolsey (1987), fixed and flattened for $2-4 \mathrm{~h}$ in $4 \%$ PFA at room temperature, and cut tangentially (parallel to layer IV) on a vibratome (Leica VT1000S or Dosaka Zero1) into $100 \mu \mathrm{m}$ sections and subject to cytochrome oxidase (CO) staining (Wong-Riley et al., 1978). Sections were incubated with CO reaction solution free-floating for $2 \mathrm{~h}$ at room temperature or $10-14 \mathrm{~h}$ at $4^{\circ} \mathrm{C}$. After visual detection of stain, sections were washed with PBS 3 times and mounted with Aqua Polymount (Polysciences).

Nissl staining. Nissl stain, which marks cell bodies, was used to reveal cortical "barrel" cytoarchitecture. Briefly, animals were perfused transcardially with ice-cold PBS followed by 4\% PFA in PBS. Barrel cortex was 
cut tangentially on a vibratome (Leica VT1000S or Dosaka Zero1) into $50-\mu \mathrm{m}$-thick sections. Sections were then mounted and dried for a day on a slide warmer at $37^{\circ} \mathrm{C}$. Slides were dehydrated and rehydrated in graded alcohol, and then fixed in 10\% Formalin (Sigma-Aldrich), and stained with $2 \%$ cresyl violet solution for $15 \mathrm{~min}$. After dehydration with graded alcohol and xylene, slides were mounted with Cytoseal (RichardAllen Scientific). The density of neurons in barrel walls and hollows was determined in three representative barrels (b2, c2, and d2) by marking the cells within a closed fixed contour drawn using Neurolucida Software (MicroBrightField). The average cell density of these three barrels was calculated for each animal and compared between genotypes. All counts were done blind to the genotype.

Golgi staining and analysis of dendrites and spines. Golgi-Cox staining was done as described previously (Datwani et al., 2002a). One hundred micrometer serial coronal sections were cut using a Microslicer (Dosaka). Layer IV spiny stellate neurons whose cell bodies were located at the midlevels of each section and whose dendrites were isolated from those of neighboring neurons were randomly selected from the posteromedial barrel subfield under a light microscope at $40 \times$ (or $20 \times$ ). Dendrites were reconstructed in three dimensions at $100 \times$ (or $40 \times$ ) using Neurolucida software (MicroBrightField). Wedge analysis, which represents the length of dendritic processes binned every $30^{\circ}$, was performed for each neuron using Neuroexplorer (MicroBrightField). Dendritic asymmetry was evaluated by calculating the dendritic length in the hemisphere $\left(180^{\circ}\right)$ with the greatest length of dendrites relative to the total dendritic length in a given neuron. The selection of neurons and the dendritic reconstructions were repeated independently by different investigators to verify the results. Spine analysis was performed on the longest dendrites from each neuron at $100 \times$ with an oil-immersion lens. All of these experiments were done blind to genotypes.

Antibodies. Primary antibodies were as follows: anti-NeuN (1:500) and anti-vesicular glutamate transporter 2 (vGlut2) (1:500) from Millipore Bioscience Research Reagents, and anti-serotonin transporter (5HTT) $(1: 10,000)$ from DiaSorin. Secondary antibodies were as follows: mouse IgG-Alexa 488 (1:500), guinea pig IgG-Alexa 488 (1:500) from Invitrogen, and goat IgG (BA-1000; 1:200) from Vector Laboratories.

Immunofluorescence. Mice were perfused, barrel cortex was flattened, and $100 \mu \mathrm{m}$ tangential sections were cut as explained above. Sections remained free-floating for all incubations and washes. Briefly, tissue was permeabilized with $0.7 \%$ Triton X-100 in PBS for $20 \mathrm{~min}$, incubated with $0.1 \mathrm{M}$ glycine for $30 \mathrm{~min}$, and then blocked with $1 \%$ normal goat serum (NGS) and $2 \mathrm{mg} / \mathrm{ml} \mathrm{BSA} \mathrm{in} \mathrm{PBS} \mathrm{containing} \mathrm{0.01 \%} \mathrm{Triton} \mathrm{X-100} \mathrm{(PBST).}$ Sections were then transferred to the primary antibody for incubation overnight at $4^{\circ} \mathrm{C}$ with appropriate dilution in PBST with $1 \%$ NGS. After washing six times in PBST, sections were incubated in the secondary antibody for $2 \mathrm{~h}$ at room temperature and then washed again for three times followed by a postfix of the sections with $4 \%$ PFA, and then mounting with Fluoromount-G (EMS). Immunolabeling was visualized with a fluorescence microscope and images were collected with a Leica DM confocal scanning microscope using a $10 \times$ objective with the channels for Cy3 (red) and Alexa 488 (green) used sequentially.

Whisker lesion experiments. Whisker lesion experiments were done as previously described (Datwani et al., 2002b). Briefly, pups were anesthetized on ice and whiskers on the left side of the snout were visualized under a light microscope. The $\mathrm{C}$ (center) row of whiskers and whisker follicles from P1 and P5 pups were cauterized with a lesion generator (Muromachi Kikai). After cauterization, the pups were revived in a warmed chamber and returned to their mother. The animals were then killed at P7-P8 (for P1 lesions) or P9-P10 (for P5 lesions). For 5HTT immunohistochemistry, $100 \mu \mathrm{m}$ tangential sections of the cerebral cortex were used. For quantitative analysis, 5HTT-immunostained tangential cortex sections were examined under a light microscope (Leica DMR), and images of the barrel field were acquired using a DC300F digital camera (Leica). Measurements of the entire large whisker representation areas and areas devoted to row $\mathrm{C}$ and row $\mathrm{D}$ were made using Image-Pro Plus software (Nippon Roper). Whisker pads were removed from the snout and fixed with $4 \%$ PFA overnight at $4^{\circ} \mathrm{C}$. PFA (4\%) was exchanged to $30 \%$ sucrose for cryoprotection for $2 \mathrm{~d}$ at $4^{\circ} \mathrm{C}$, cryoprotected in $30 \%$ sucrose, and sectioned at a $60 \mu \mathrm{m}$ in the tangential plane.
These sections were stained with hematoxylin-eosin to confirm the extent and precision of row $\mathrm{C}$ follicle lesions. Animals with lesions that spread beyond row $\mathrm{C}$, or did not include at least the first two whiskers in row $\mathrm{C}$, were excluded from analysis. These experiments were performed blind to genotypes.

Slice electrophysiology. Acute TC slices were prepared as described previously (Lu et al., 2001). The artificial CSF (ACSF) (124 mM NaCl, $5 \mathrm{~mm}$ $\mathrm{KCl}, 1.25 \mathrm{~mm} \mathrm{NaH}_{2} \mathrm{PO}_{4}, 1.3 \mathrm{~mm} \mathrm{MgSO} 4,2 \mathrm{~mm} \mathrm{CaCl}_{2}, 26 \mathrm{~mm} \mathrm{NaHCO}_{3}$, and $11 \mathrm{~mm}$ glucose, $\mathrm{pH} 7.2$ and $290-300 \mathrm{mOsm}$ ) was saturated with $95 \%$ $\mathrm{O}_{2}$ and $5 \% \mathrm{CO}_{2}$. The whole-cell recording solution contained $99 \mathrm{~mm}$ cesium gluconate, $17.5 \mathrm{~mm} \mathrm{CsCl,} 8 \mathrm{~mm} \mathrm{NaCl}, 10 \mathrm{~mm}$ HEPES, $0.2 \mathrm{~mm}$ EGTA, 4 mM Mg-ATP, $0.3 \mathrm{~mm}$ GTP, $7 \mathrm{~mm}$ phosphocreatine, and $10 \mathrm{~mm}$ BAPTA. BAPTA was included in the pipette to prevent inadvertent potentiation of the postsynaptic neuron.

Stimuli were applied to the VB thalamus through bipolar sharpened and insulated stainless-steel microelectrodes (FHC). Data were collected and analyzed on-line using a computer-driven acquisition system (National Instruments) and software that was written under the Igor (WaveMetrics) programming environment.

EPSCs were measured in voltage-clamp mode using in vitro whole-cell voltage-clamp recording techniques following published protocols ( $\mathrm{Lu}$ et al., 2001). To confirm that excitatory layer IV neurons were recorded, cells were filled with $2 \%$ biocytin and the slices were stained using Vectastain Elite $\mathrm{ABC}$ kit (Vector Laboratories). To evaluate and monitor the health of the cell, input and series resistances were continuously monitored, with cells that had $<300 \mathrm{M} \Omega$ input resistance or drifted $>20 \%$ discarded. Only responses that exhibited short and constant latencies that did not change with increasing stimulus intensity were considered monosynaptic. Because the responses in young cells tend to drift down if the stimulation intensity or the stimulation frequency is high, one-half saturating stimulation strength with a relatively low stimulation frequency (10-15 ms interval) was used to evoke stable EPSCs. Before any experimental manipulation, $10-15 \mathrm{~min}$ of stable baseline response was acquired. EPSC amplitudes were calculated by subtracting the mean current during a fixed 3-4 ms window before the stimulus artifact from the mean current during a similar window at the peak of the EPSC.

To measure the AMPA/NMDA current ratio, which is a gross measure of the relative contribution of AMPA and NMDA receptor mediated currents across a population of synapses, we first isolated the AMPA response by voltage clamping the cell at hyperpolarized membrane potentials $(-70 \mathrm{mV})$ while stimulating the thalamus. We then depolarized the cell to $+40 \mathrm{mV}$ to relieve the $\mathrm{Mg}^{2+}$ block of the NMDA receptor and added NBQX (2,3-dioxo-6-nitro-1,2,3,4-tetrahydrobenzo[f] quinoxaline7-sulfonamide) $(10 \mu \mathrm{M})$ (Tocris) to the perfusate to block AMPA and kainate receptors, leaving a pure NMDA receptor response. These experiments were done at "normal" (half saturating) stimulus strength as a gross measure of the relative amplitude of the AMPA and NMDA receptor currents (Crair and Malenka, 1995; Lu et al., 2001, 2003) in the presence of GABAergic antagonists ( $10 \mu \mathrm{M}$ bicuculine, cesium ions in the whole-cell solution block $\mathrm{GABA}_{\mathrm{B}}$ responses).

For analysis of AMPA “evoked miniature" events, stable whole-cell voltage-clamp recordings were established at $-70 \mathrm{mV}$ holding potential and the $\mathrm{Ca}^{2+}$ in the ACSF was exchanged for $\mathrm{Sr}^{2+} \cdot \mathrm{Sr}^{2+}$-based ACSF desynchronizes neurotransmitter release, allowing isolated evoked miniature currents to be analyzed (Xu-Friedman and Regehr, 1999). Evoked miniature events were recorded in $1 \mathrm{~s}$ epochs every $2 \mathrm{~s}$ in Igor Pro using $\operatorname{ACSF}\left(2 \mathrm{mM} \mathrm{Sr}^{2+}\right)$ containing $100 \mu \mathrm{M}$ picrotoxin and $50 \mu \mathrm{M}$ D-AP5 [D-([amino])-2-amino-5 phosphopentanoic acid] (Tocris) to eliminate inhibitory currents and possible NMDA receptor current contamination, respectively. Data were imported into Mini Analysis (Synaptosoft), amplitude thresholds were set at 2.5 times root mean square noise, and at least 80 events were identified and used for analysis in each cell. Temporal windows were chosen to represent both the fast and slow components of miniature event decay times. A significant advantage of measuring "evoked minis" is that the population is dominated by TC synapses, as opposed to measuring spontaneous minis in tetrodotoxin, which is a random sample of all synapses on the cell.

LTP was induced using a pairing protocol, in which postsynaptic depolarization is "paired" with presynaptic stimulation in whole-cell 
voltage-clamp mode (Lu et al., 2001). For these experiments, BAPTA was excluded from the pipette solution, and EPSCs from somatosensory cortex layer IV neurons elicited with thalamic stimulation were recorded at $-70 \mathrm{mV}$ until a stable baseline of $10 \mathrm{~min}$ was obtained. Pairing was then initiated by switching to a holding potential of $-10 \mathrm{mV}$ and stimulating at $1 \mathrm{~Hz}$ for $100 \mathrm{~s}$. The holding potential was then switched back to $-70 \mathrm{mV}$ after pairing. The percentage EPSC change was calculated as the mean EPSC amplitude of 20 sweeps at 35 min after pairing minus the mean EPSC amplitude of 20 sweeps right before pairing (baseline amplitude) divided by the baseline amplitude.

Paired-pulse measurements were done by isolating the NMDA receptor mediated current as described above, and then eliciting pairs of stimuli at interstimulus intervals (ISIs) of 50, 75, 100, and $500 \mathrm{~ms}$. Each condition was presented in pseudorandom order. Ratios were then computed as the mean amplitude response to the second stimulus over the response to the first stimulus.

For (+)-5-methyl-10,11-dihydro-5 $H$-dibenzo (a,d)cyclohepten-5,10-imine maleate (MK801) experiments, NMDA current was isolated and only cells responding with a significant amount of NMDA current $(>25 \mathrm{pA})$ were used. After acquiring a stable baseline response (10-15 $\mathrm{min})$, the stimulation was stopped and ACSF containing (+)-MK801 (10 $\mu \mathrm{M}$; Tocris Cookson) was perfused onto the slice ( $1 \mathrm{ml} / \mathrm{min}$ flow rate). After 10 min (to allow enough time for MK801 to equilibrate in the recording chamber), stimulation was resumed and response was recorded until no NMDA current could be detected for $>5 \mathrm{~min}$. The time course of MK801-dependent blockade was analyzed by normalizing all of the responses to the amplitude of the first NMDA response after MK801 was applied, and the blockade rates were estimated by fitting a double-exponential function $\left(\mathrm{A} 1 \mathrm{e}^{-t / \tau 1}+\mathrm{A} 2 \mathrm{e}^{-t / \tau 2}\right)$ to the decay and calculating a weighted time constant, $\tau$ weighted $=\tau 1 \times \mathrm{A} 1 /(\mathrm{A} 1+\mathrm{A} 2)+\tau 2 \times$ $\mathrm{A} 2 /(\mathrm{A} 1+\mathrm{A} 2)$, from the fit parameters.

\section{Results}

\section{Generation of CxAC1KO mice}

As the first step to generate $\mathrm{CxAC1KO}$ mice, we examined whether our floxed AC1 (AC1-flox) allele, in which the putative promoter and exon 1 of $\mathrm{AC} 1$ are flanked by two loxP sites (Fig. $1 A$ ), is functional. To confirm that Cre-mediated recombination of the floxed allele produces a null allele, we expressed the Cre recombinase protein in the germline of $\mathrm{AC}^{\text {flox/+ }}$ mice and obtained progeny heterozygous for the AC1- $\Delta$ allele, in which the floxed DNA sequences were deleted by Cre-mediated recombination (Fig. $1 A$ ). Then, we intercrossed $\mathrm{AC}^{\Delta /+}$ mice to generate $\mathrm{AC1}^{\Delta / \Delta}$ mice. RT-PCR analyses using primer sets for exons downstream of the floxed sequence detected $\mathrm{AC} 1$ transcripts in the $\mathrm{AC} 1^{\text {flox/flox }}$ but not the $\mathrm{AC} 1^{\Delta / \Delta}$ brains (Fig. $1 B$ ). These results clearly show that the AC1- $\Delta$ allele is a null allele of AC1.

It is known that global disruption of the $\mathrm{AC} 1$ gene in barrelless $(b r l)$ mice completely abolishes barrel patterning and partially impairs barreloids in the VB thalamus (Welker et al., 1996; Abdel-Majid et al., 1998). We examined whether AC1 ${ }^{\Delta / \Delta}$ mice demonstrate phenotypes similar to global AC1-deficient mice. We analyzed patterning of the morphological body map in barrel
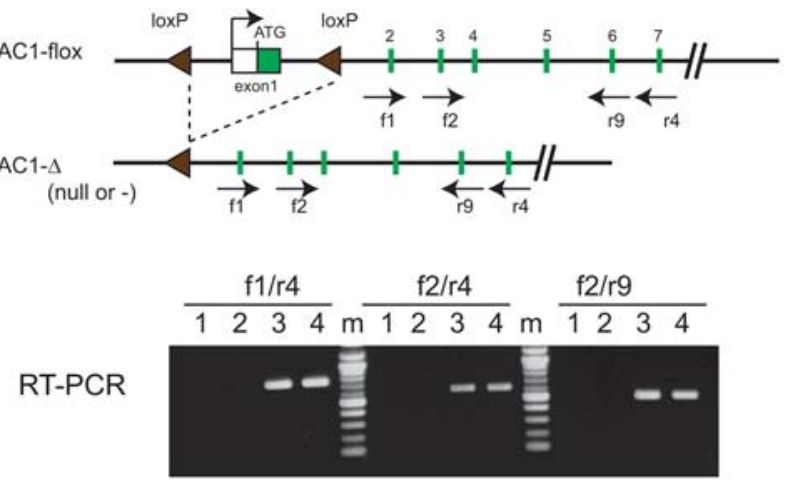

Barrels (Nissl)

Barreloids

Barrelettes
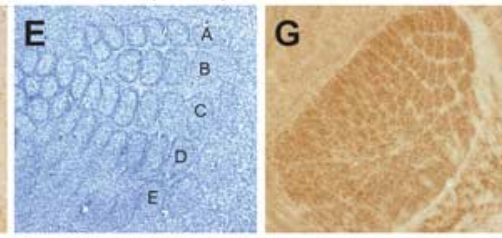

I
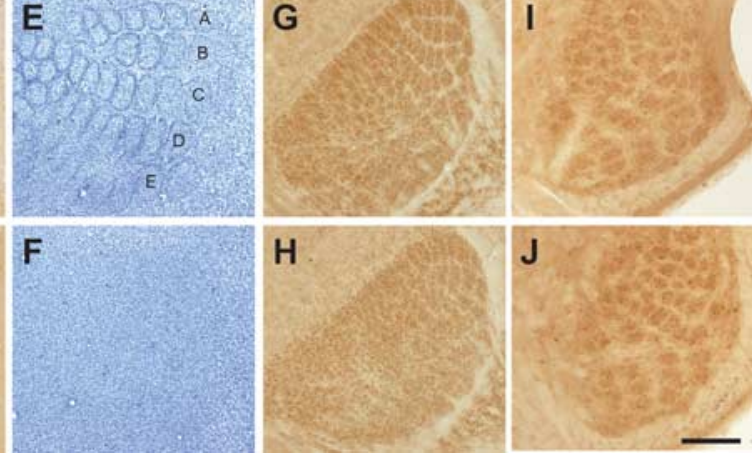

Figure 1. Cre-mediated recombination on the AC1-flox allele produces AC1-null allele. $A$, Schematics of $A C 1^{\text {flox }}$ and $\mathrm{AC1}{ }^{\Delta(=\text { null or }-)}$ alleles. $\mathrm{AC1}{ }^{\Delta}$ allele was generated by expressing (re recombinase in the germline of $\mathrm{AC} 1^{\text {flox } /+}$ mice, in which exon 1 and the putative promoter of the AC1 gene are flanked by two loxP sites. B, RT-PCR using primers specific for exons

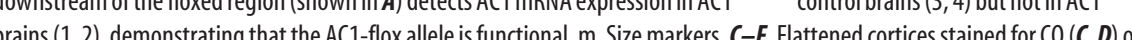
Nissl $(\boldsymbol{E}, \boldsymbol{F})$ demonstrate that $A C 1^{\Delta / \Delta}$ mice $(\boldsymbol{D}, \boldsymbol{F})$ completely lack the cortical barrel pattern, unlike control (wild-type) mice $(\boldsymbol{C}, \boldsymbol{E})$. $G, \boldsymbol{H}$, Bas loids in $\mathrm{VB}$ thalamus of $\mathrm{AC}{ }^{\Delta / \Delta}$ mice $(\boldsymbol{H})$ are not as distinct as those of $\left(\mathrm{AC}^{+/ \Delta}\right)$ control mice $(\boldsymbol{G}) . \boldsymbol{I}, \boldsymbol{J}$, Both control ) and $A C 1^{\Delta / \Delta}$ mice have normal barrelettes in the brainstem principal nucleus. The whisker-related patterns in $\mathrm{AC}^{\Delta / \Delta}$ mice throughout the trigeminal pathway are similar to those reported in barrelless (brl) and $\mathrm{AC1}^{-1-}$ mice (Welker et al., 1996; Abdel-Majid et al., 1998), further confirming that the $A C^{\text {flox }}$ allele is functional. Scale bar: $(-F, 500 \mu \mathrm{m} ; \boldsymbol{G}, \boldsymbol{H}, 250 \mu \mathrm{m} ; \boldsymbol{I}, \boldsymbol{J}, 125 \mu \mathrm{m}$.

cortex of $\mathrm{AC} 1^{\Delta / \Delta}$ and wild-type mice by CO histochemistry and Nissl staining. CO-dense patches reflect the gross organization of both TC afferent terminals and target neurons, and Nissl staining reveals the layer IV cytoarchitecture. We found that barrel map patterning was completely disrupted in $\mathrm{AC}^{\Delta / \Delta}$ mice but normal in wild-type controls (Fig. $1 C-F$ ). In addition, the pattern of VB thalamic barreloids in $\mathrm{AC} 1^{\Delta / \Delta}$ mice was not as distinct as those seen in control $\left(\mathrm{ACl}^{/+/ \Delta}\right.$ ) mice (Fig. $\left.1 G, H\right)$. Finally, both control $\left(\mathrm{ACl}^{1+/ \Delta}\right)$ and $\mathrm{ACl}^{\Delta / \Delta}$ mice had normal barrelettes in the somatosensory brainstem (Fig. 1I,J). These phenotypes were essentially identical with those observed in $b r l$ mice, and further confirm that the AC1-flox allele produces an AC1-null allele on Cre-mediated recombination. Hereafter we refer to the $\mathrm{ACl}^{\Delta}$ allele as the $\mathrm{ACl}^{\text {null }}$ (or $\mathrm{ACl}^{-}$) allele.

We previously generated Emxl-Cre mice, in which Cremediated recombination is first detectable in the dorsal telencephalon at embryonic day 10 (E10) and is restricted to cortical excitatory neurons throughout the animal's life (Fig. 2A) (Iwasato et al., 2000, 2004). In this study, we used the knock-in- $\Delta$ Neo $(\mathrm{K} \Delta \mathrm{N})$ line for most experiments and the $\mathrm{Tg} 3$ line or both in a few cases (Iwasato et al., 2000, 2004). We crossed these Cre mice with $\mathrm{AC} 1^{+/-}$mice to obtain double heterozygous mice, and further crossed these with $\mathrm{ACl}^{-1-}$ mice to obtain Emxl-Cre:AC1 ${ }^{-1-}$ mice. These mice were then crossed with $A C 1^{\text {flox/flox }}$ or $A C 1^{\text {flox/+ }}$ 

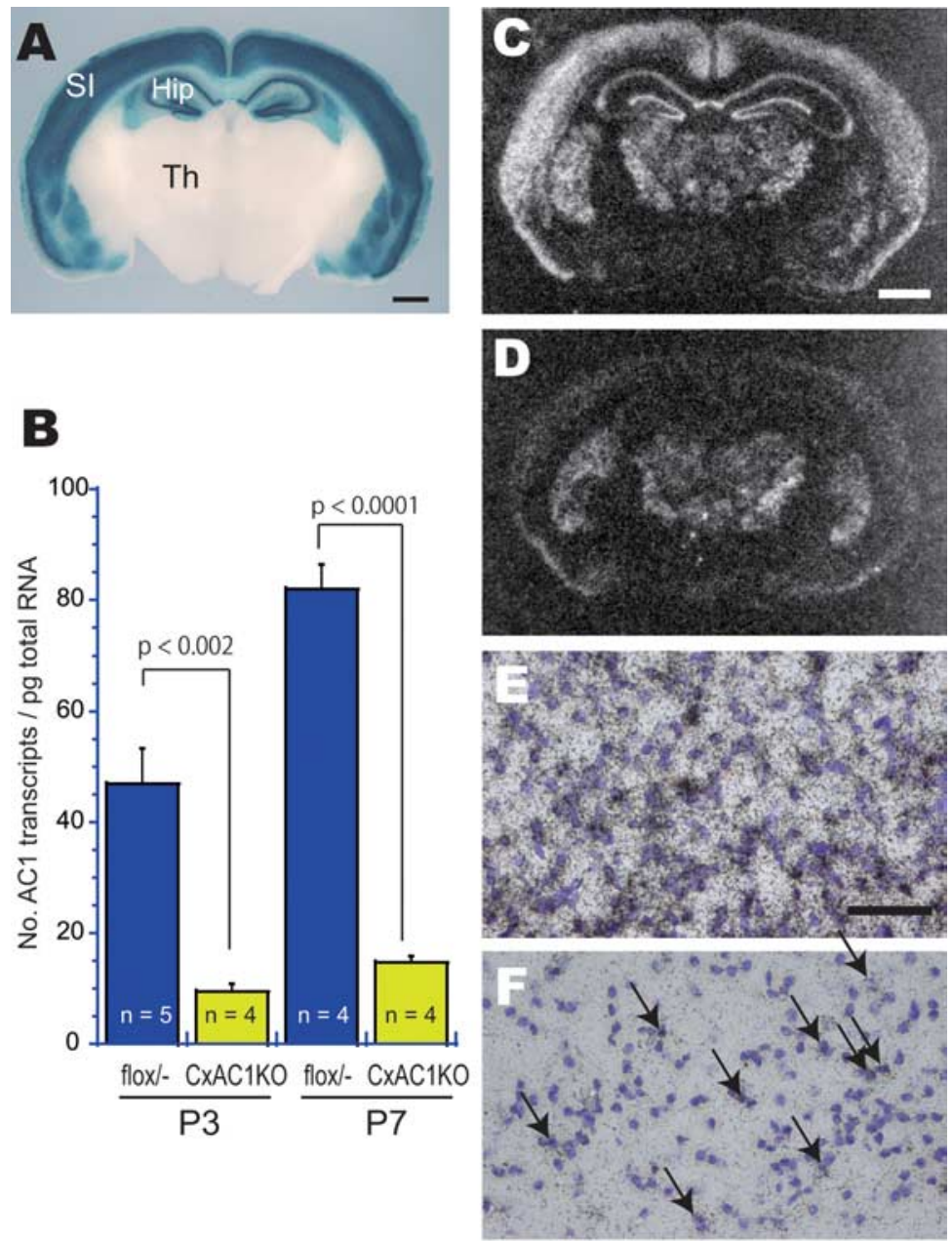

Figure 2. CXAC1KO mice generated using Cre expression driven by Emx1 promoter. $A$, LaCZ staining of 400- $\mu \mathrm{m}$-thick coronal sections from progeny of Emx1-Cre $(K \Delta N)$ mice crossed with CAG-CAT-Z reporter mice demonstrates that Cre-mediated recombination is specific to neocortex and hippocampus from embryonic stages (data not shown) to adulthood. For more information, see Iwasato et al. (2000, 2004). SI, Barrel cortex; Hip, hippocampus; Th, thalamus. B, Quantitative RT-PCR of AC1 ${ }^{\text {flox } /-}$ and CXAC1K0 mice barrel cortex at P3 and P7. Number of AC1 transcripts per picogram of total RNA for P1 flox/ $-(n=5), \mathrm{P} 1$ CXAC1KO $(n=4), \mathrm{P} 7 \mathrm{flox} /-(n=4)$, and P7 (XAC1KO $(n=4)$ are as follows (mean \pm SEM): 46.86 $\pm 6.37,9.36 \pm 1.42,81.96 \pm 4.43$, and $14.83 \pm 1.09$; Student's $t$ test. $C, \boldsymbol{D}$, In situ hybridization of $A C 1$ mRNA in coronal sections of $P 7$ brains of $A C 1^{\text {flox } /-}(\boldsymbol{C}, E)$ and CXAC1KO $(\boldsymbol{D}, \boldsymbol{F})$ mice at P7. A few AC1-expressing neurons ( $\boldsymbol{F}$, arrows), presumably GABAergic interneurons, are observed in CXAC1KO cortex. Scale bars: $A, C, D, 1 \mathrm{~mm} ; \boldsymbol{E}, \boldsymbol{F}, 50 \mu \mathrm{m}$.

mice to obtain Emx1-Cre:AC1 ${ }^{\text {flox/- }}$ mice and their littermate controls (Emx1-Cre:AC1 ${ }^{+/-}, \mathrm{ACl}^{\text {flox/- }}$, and $\mathrm{ACl}^{+/-}$). Emx1Cre:AC1 ${ }^{\text {flox } /-}$ mice constitute CxAC1KO mice.

We compared levels of AC1 expression in the barrel cortex of $\mathrm{CxAC} 1 \mathrm{KO}$ and $\mathrm{AC1} 1^{\text {flox/- }}$ mice at P3 and P7 by quantitative RTPCR. At P3 and P7, the level of AC1 mRNA present in the barrel cortex of $\mathrm{CxAC} 1 \mathrm{KO}$ mice was reduced to 20.0 and $18.1 \%$, respectively, of the levels in barrel cortex of age-matched $\mathrm{AC} 1^{\text {flox/- }}$ control mice (Fig. $2 B$ ). These ratios are similar to the proportion of GABAergic neurons in the barrel cortex (Lin et al., 1985; Beaulieu, 1993). To further confirm the cortex-restricted AC1 disruption in $\mathrm{CxAC} 1 \mathrm{KO}$ mice, we examined the distribution of $\mathrm{AC} 1$ mRNA by in situ hybridization (Fig. 2C-F). We found that the amount of AC1 mRNA in the neocortex and hippocampus of CxAC1KO mice was much lower than that of control ( $\mathrm{AC} 1^{\text {flox/- }}$ ) mice both at P1 (data not shown) and P7 (Fig. 2C,D). Other brain regions exhibited similar levels of $\mathrm{AC} 1 \mathrm{mRNA}$ in $\mathrm{CxAC} 1 \mathrm{KO}$ and control $\left(\mathrm{ACl}^{\text {flox/- }}\right.$ ) mice. We detected $\mathrm{AC1}$ expression in only a few cells of the CxAC1KO cortex (Fig. 2F). These AC1-expressing cells are presumably inhibitory neurons, because we and others previously demonstrated that the Emx1 lineage does not give rise to the GABAergic neurons of the neocortex (Iwasato et al., 2000, 2004; Chan et al., 2001; Gorski et al., 2002).

\section{Barrel wall formation, but not the gross barrel pattern, is disturbed in CXAC1KO mice}

Intriguingly, analyses of the gross barrel patterning in $\mathrm{CxAC} 1 \mathrm{KO}$ somatosensory cortex, using CO staining ( $n=6$ for both genotypes) as well as presynaptic TC axonal clustering by immunostaining for a TC axon marker, vGlut2 $(n=3$ for both genotypes), did not reveal any notable differences from control mice (Fig. 3). Layer IV neuronal organization into barrel walls was examined with Nissl staining $(n=8$ for controls and $n=11$ for $\mathrm{CxAC} 1 \mathrm{KO}$ mice) (Fig. 3C,D) and immunostaining for NeuN, which labels neuronal cell bodies ( $n=3$ for both genotypes) (Fig. $3 E, F)$. Both staining methods revealed no qualitative difference between $\mathrm{CxAC} 1 \mathrm{KO}$ and control mice. We also examined the thalamic barreloid pattern using CO staining in $\mathrm{CxAC} 1 \mathrm{KO}$ mice and found a pattern similar to control mice (data not shown). These phenotypes, which were strikingly different from those observed in global AC1 KO mice (Fig. $1 C-H$ ), indicate that $\mathrm{AC} 1$ function in cortical excitatory neurons is not essential for the gross patterning of cortical barrels and VB thalamic barreloids. However, quantitative analysis of Nissl-stained sections showed that there is a small but statistically significant decrease in the wall-to-hollow ratio of neuronal densities in barrels of $\mathrm{CxAC} 1 \mathrm{KO}$ mice $(1.28 \pm 0.032 ; n=11)$ compared with those of $\mathrm{ACl}^{\mathrm{flox} /-}$ control mice $(1.47 \pm 0.035 ; n=8 ; p<0.01$; Student's $t$ test). Therefore, cortical AC1 appears to play a role in the emergence of fine features of layer IV barrel cytoarchitecture.

\section{Dendritic orientation of layer IV neurons is impaired in the barrel cortex of $\mathrm{CxAC1KO}$ mice}

A prominent feature of barrel cortex cytoarchitecture is the asymmetric orientation of layer IV neuron dendrites toward the barrel hollow. To determine whether layer IV neurons require cortical AC1 function to acquire this asymmetric dendritic morphology, we performed Golgi staining and reconstructed the dendrites of spiny stellate neurons in layer IV barrel cortex of $\mathrm{CxAC} 1 \mathrm{KO}$ and control $\left(\mathrm{ACl}^{\text {flox/-}}{ }^{-}\right.$) mice (Fig. $\left.4 A-D\right)$. A total of 60 neurons were analyzed, with 24 control neurons from six animals and $36 \mathrm{CxAC1KO}$ neurons from nine animals. Dendritic asymmetry was determined by calculating the dendritic length in the hemisphere $\left(180^{\circ}\right)$ with the greatest length of dendrites relative to the total dendritic length $\left(360^{\circ}\right)$ in a given neuron (for more details, see Materials and Methods). This analysis showed that the asymmetry of CxAC1KO layer IV neuron dendrites was reduced compared with that of control mice 
$(0.95 \pm 0.011$ for controls and $0.86 \pm 0.017$ for CxAC1KOs; $p<0.01$, Student's $t$ test) (Fig. 4E). Dendritic span, defined as the largest distance between the most distal dendrite tips of the cell, was also significantly larger in CxAC1KO mice than that of control mice (96.2 $\pm 5.9 \mu \mathrm{m}$ for controls and $117.5 \pm 6.3$ $\mu \mathrm{m}$ for CxAC1KOs; $p<0.05$, Student's $t$ test), consistent with the reduced asymmetry of these neurons (Fig. 4F).

To verify these results, the analysis was repeated on the same sections by a different investigator, who reconstructed a total of 37 neurons, 12 neurons from 7 control mice and 25 neurons from $10 \mathrm{CxAC} 1 \mathrm{KO}$ mice. In the end, only three neurons (two $\mathrm{CxAC} 1 \mathrm{KO}$ and one control neuron) from the randomly chosen samples were selected for reconstruction by both investigators. This second analysis confirmed that the asymmetry of CxAC1KO layer IV neurons is reduced on average compared with control mice $(0.94 \pm 0.023$ for controls and $0.85 \pm 0.023$ for CxAC1KOs; $p<$ 0.05 , Student's $t$ test). Dendritic span was also found to be relatively larger in CxAC1KO mice compared with controls (105.7 $\pm 10.1 \mu \mathrm{m}$ for controls and $128.3 \pm$ $7.6 \mu \mathrm{m}$ for CxAC1KOs; $p=0.09$, Student's $t$ test). In contrast, analyses of the total dendritic length $(421.7 \pm 55.9 \mu \mathrm{m}$ for controls and $466.4 \pm 43.4 \mu \mathrm{m}$ for CxAC1KOs; $p=0.61$, Student's $t$ test) and spine density $\left(0.69 \pm 0.04 \mu \mathrm{m}^{-1}\right.$ for con-

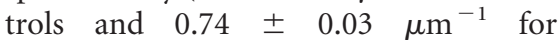
CxAC1KOs; $p=0.38$, Student's $t$ test) revealed no difference between genotypes. These results indicate that AC1 function in the cortex is required for layer IV neurons in barrel cortex to acquire their typical asymmetric dendritic morphology.

\section{Lesion-induced plasticity of the TC axonal pattern is not changed in CxAC1KO mice}

The area of cortex devoted to a particular peripheral sense organ changes if the pattern of sensory input changes. For example, if a row of whiskers and whisker follicles is damaged neonatally, the area of cortex devoted to the damaged row shrinks and the neighboring rows expand (Van der Loos and Woolsey, 1973). In mouse barrel cortex, the critical period for this type of plasticity ends by P4 (Woolsey and Wann, 1976; Durham and Woolsey, 1984; Datwani et al., 2002b; Rebsam et al., 2005).

We examined lesion-induced map plasticity of TC axon clustering in $\mathrm{CxAC} 1 \mathrm{KO}$ and control mice by electrocautery of the center (C) row of whiskers and whisker follicles at P1 or P5. Mice were analyzed at P7-P8 (for P1-lesion) or P9-P10 (for P5-lesion) by immunostaining for 5HTT, which is specifically expressed in TC axon terminals (Lebrand et al., 1998; Rebsam et al., 2002) (Fig. 5A-D). Quantification of map plasticity was performed by normalizing each barrel area with respect to the area of the entire large barrel field and
Control
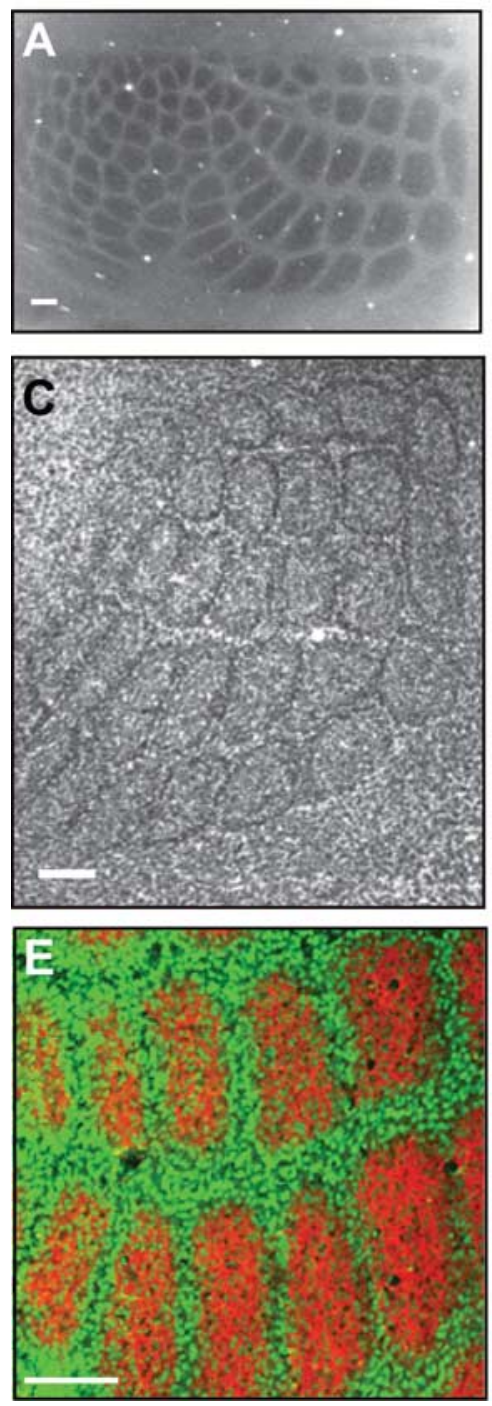

Figure 3. Grossly normal cortical barrel map in CXAC1K0 mice. $\boldsymbol{A}, \boldsymbol{B}$, Tangential sections from P29 control $\left(\mathrm{AC} 1^{\text {flox } /-}\right)(\boldsymbol{A})$ and CXAC1KO $(\boldsymbol{B})$ mice stained with $C 0$. Whisker barrel patterns are indistinguishable between genotypes. $\boldsymbol{C}, \boldsymbol{D}$, Nissl-stained tangential sections from P24 control ( $\left.A C 1^{\text {flox/- }}\right)(\boldsymbol{C})$ and CXAC1KO (D) mice. As in control mice, layer IV neurons in CXAC1 K0 mice organize into a grossly normal barrel "wall" and "hollow" pattern characteristic of rodent somatosensory cortex. $\boldsymbol{E}, \boldsymbol{F}$, Tangential sections from P10 control ( $\left.A C 1^{\text {flox/- }}\right)(\boldsymbol{E})$ and CXAC1KO $(\boldsymbol{F})$ mice immunostained with anti-vGlut2 antibody in red and anti-NeuN in green, which selectively label TC afferents and neuronal cell bodies, respectively. The barrel pattern is qualitatively similar in the two genotypes, showing that the gross presynaptic and postsynaptic patterning of barrels in CXAC1KO mice is not impaired. However, a quantitative analysis of the patterning of layer IV neurons into barrel walls and hollows reveals a small but statistically significant decrease in the wall-to-hollow ratio in the CXAC1K0 mice $(1.28 \pm 0.032 ; n=11)$ compared with AC $1^{\text {flox } /-}$ control mice $(1.47 \pm$ $0.035 ; n=8 ; p<0.01$, Student's $t$ test). Scale bars, $100 \mu \mathrm{m}$.

then calculating the ratio of $\mathrm{D}$ row to $\mathrm{C}$ row area. We found that $\mathrm{CxAC1KO}$ mice in which whiskers were cauterized at $\mathrm{P} 1$ had a similar degree of map plasticity as littermate control mice (D/C ratio for control mice: $2.67 \pm 0.24$ (mean \pm SEM),$n=7$; and for CxAC1KO mice: $3.55 \pm 0.69 ; n=9 ; p=0.300, t$ test) (Fig. $5 E-G$ ) (for details of the quantification, see Materials and Methods). Whisker cauterization at P5 did not induce map plasticity in either CXAC1KO or control mice (Fig. $5 C-G$ ). Similar results were obtained when examining lesion-induced map plasticity of layer IV cytoarchitecture with Nissl-stained sections (supplemental Fig. 1, available at www.jneurosci.org as supplemental material). These results indicate that cortical AC1 function does not play a role in lesion-induced plasticity and in the closure of the critical period for this plasticity. 

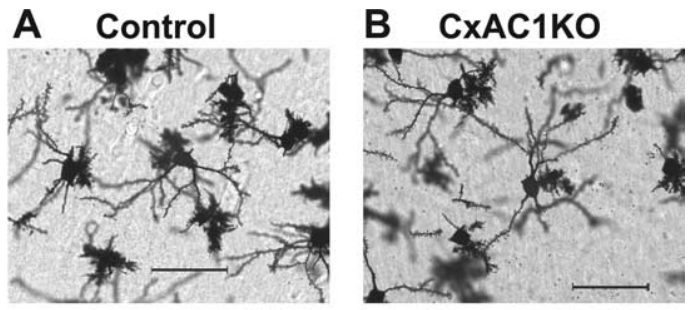

C

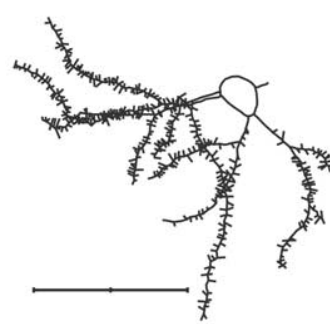

D
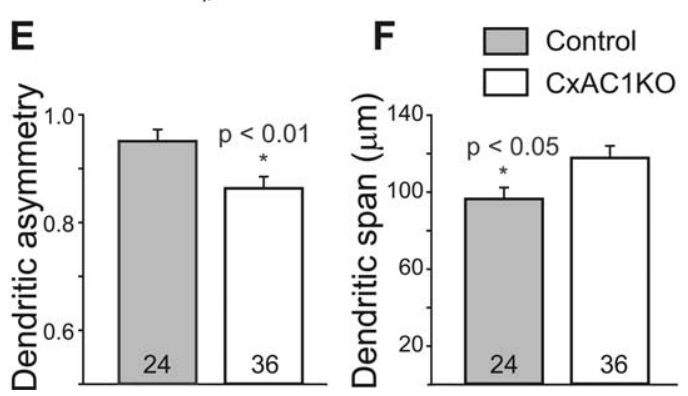

Figure 4. Dendritic asymmetry of layer IV spiny stellate neurons in CXAC1KO mice is reduced compared with littermate controls. $A-D$, Examples of Golgi-stained layer IV spiny stellate neurons in the barrel cortex $(\boldsymbol{A}, \boldsymbol{B})$ and their computer-aided reconstructions $(\boldsymbol{C}, \boldsymbol{D})$ in control $\left(A C 1^{\text {flox } /-}\right)(A, C)$ and $\mathrm{CXAC1KO}(\boldsymbol{B}, \boldsymbol{D})$ mice at P29. E, CXAC1KO mice have significantly lower $\left({ }^{*} p<0.01\right.$, Student's $t$ test) dendritic asymmetry compared with littermate controls. Dendritic asymmetry, which must be $\geq 0.5$, is defined as the ratio of the dendritic length in the hemisphere with the greatest density of dendrites relative to the total dendritic length. Error bars indicate SEM. F, Dendritic field span, the greatest distance between the most distal dendrite tips of a particular layer IV spiny stellate neuron, is significantly greater $\left({ }^{*} p<0.05\right.$, Student's $t$ test) in CXAC1KO mice compared with littermate control mice. Scale bars, $50 \mu \mathrm{m}$.

\section{CxAC1KO mice have lower AMPA/NMDA ratio and fewer AMPA receptors at TC synapses}

Like many glutamatergic synapses, the AMPA/NMDA ratio increases at TC synapses during maturation, likely through the insertion of AMPA receptors at the synapse via LTP-like mechanisms (Malinow and Malenka, 2002). We previously demonstrated that $b r l$ mutants have fewer functional AMPA receptors and the developmental increase in AMPA/NMDA ratio is absent at TC synapses of $b r l$ mice ( $\mathrm{Lu}$ et al., 2003). To clarify whether these postsynaptic functional deficits in $\mathrm{brl}$ mice are specifically attributable to the absence of cortical AC1 function, we examined AMPA/NMDA ratios (Fig. 6) and AMPA receptorevoked miniature events (Fig. 7) in CxAC1KOs and littermate control mice.

We found that the AMPA/NMDA ratio at P9-P11 for CxAC1KO mice $(0.99 \pm 0.16 \mathrm{pA} ; n=8)$ was significantly lower than that of control mice $\left(1.56 \pm 0.17, n=6\right.$ for $\mathrm{AC}^{+/-} ; 1.61 \pm$ $0.22, n=6$ for Emx-Cre; $\mathrm{ACl}^{+/-} ; 1.83 \pm 0.36, n=7$ for $\mathrm{AC}^{\text {flox } /-}$; and $1.67 \pm 0.15, n=19$ for all controls; $p<0.05, t$ test) (Fig. 6C). AMPA receptor-mediated miniature events (AMPA receptor minis) at single $\mathrm{TC}$ synapses were examined by replacing $\mathrm{Ca}^{2+}$ with $\mathrm{Sr}^{2+}$ in the extracellular solution. In the presence of $\mathrm{Sr}^{2+}$, the neurotransmitter release at axon terminals is desyn-
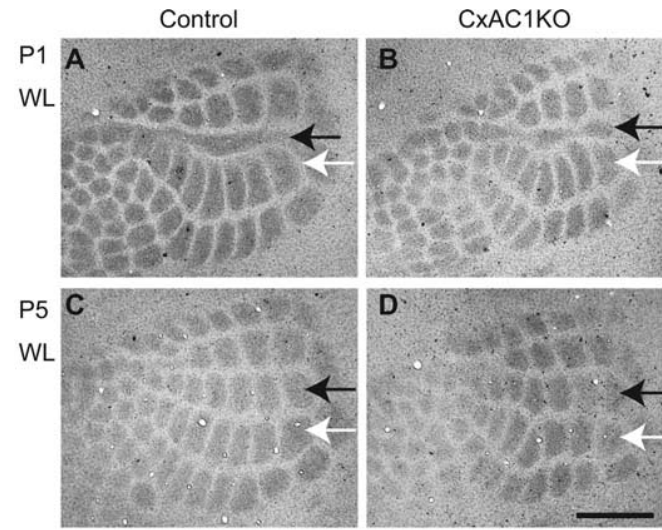

E

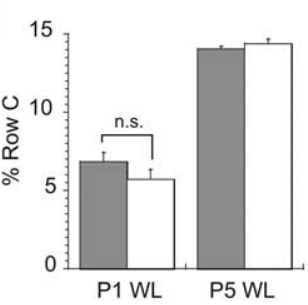

F 20
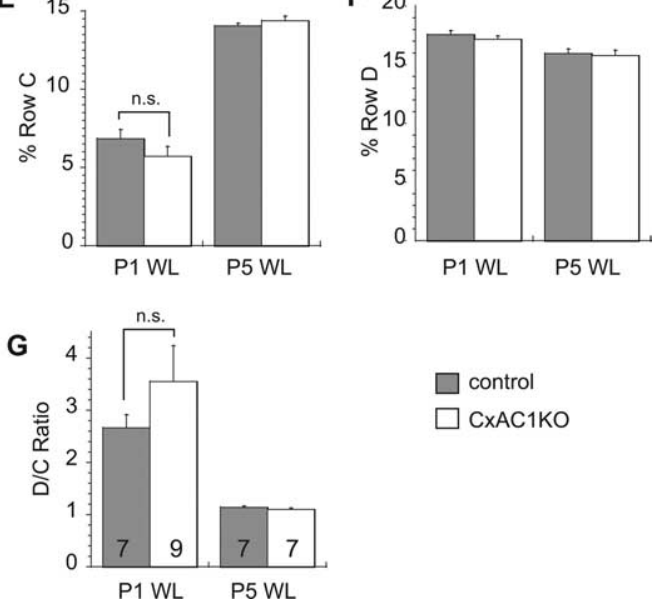

control

$\square$ CxAC1KO

Figure 5. Lesion-induced plasticity is not altered in CXAC1KO mice. $\boldsymbol{A}, \boldsymbol{B}, 5 \mathrm{HTT}$ immunohistochemistry of tangential sections from barrel cortex shows that $C$ row whisker lesioned at $P 1$ (P1WL) induces robust shrinkage of row C (black arrows) and expansion of neighboring rows (row D, white arrows) in TC axons of both $\mathrm{CxAC1KO}(B)$ and their littermate control ( $\mathrm{AC} 1^{\text {flox/- }}$ ) mice $(\boldsymbol{A})$. $\boldsymbol{C}, \boldsymbol{D}$, The critical period for this map plasticity ends by P5 in both $\mathrm{CXAC1KO}(\boldsymbol{D})$ and littermate control mice (C). $\boldsymbol{E}-\mathbf{G}$, Quantification of lesion-induced plasticity in control and CxAC1KO mice. Analyses of percentage $\operatorname{row} C(\boldsymbol{E})$ and $\operatorname{row} D(\boldsymbol{F})$ areas normalized with respect to area of the entire large whisker representation are similar between control and CXAC1KO mice. The $D / C$ ratio calculated by dividing the row $D$ area by the row $C$ area provides a plasticity index (Schlaggar et al., 1993; Datwani et al., 2002b). The D/C ratio analysis reveals no difference in TC axon map plasticity between genotypes $(\boldsymbol{G})$. Error bars indicate SEM; Student's $t$ test. Scale bar, $500 \mu \mathrm{m}$.

chronized and AMPA receptor minis are observed in response to this quantal release at single synapses (Fig. $7 A, B)(\mathrm{Xu}$-Friedman and Regehr, 1999). Evoked mini-EPSC amplitudes of CxAC1KOs were on average smaller than littermate controls at P9-P11 $\left(9.48 \pm 0.76 \mathrm{pA}\right.$ for $n=7 \mathrm{AC} 1^{\text {flox } /-}$ control vs $6.59 \pm 0.33 \mathrm{pA}$ for $n=10 \mathrm{CxAC} 1 \mathrm{KO} ; p<0.05, t$ test) (Fig. $7 C$, inset). Comparison of the evoked mini-EPSC amplitude histograms showed a shift in the peak of the distribution, with the histogram in $\mathrm{CxAC} 1 \mathrm{KO}$ mice peaking at a smaller amplitude than littermate controls (Fig. $7 C)$. In addition, $\mathrm{CxAC} 1 \mathrm{KO}$ mice had very few responses with large amplitudes (Fig. 7C). The mean cumulative probability distributions also revealed a shift in evoked mini-EPSCs in CxAC1KO mice toward smaller amplitudes compared with littermate controls (Fig. $7 D$ ). These results indicate that, in the absence of $\mathrm{AC} 1$ signaling in cortical excitatory neurons, the number of functional AMPA receptors at TC synapses is reduced, leading to smaller AMPA receptor-mediated currents and smaller AMPA/NMDA ratios. These defects are similar to those observed in $\mathrm{brl}$ mice, which were therefore attributable at least in part to the absence of $\mathrm{AC} 1$ function in cortical neurons. 

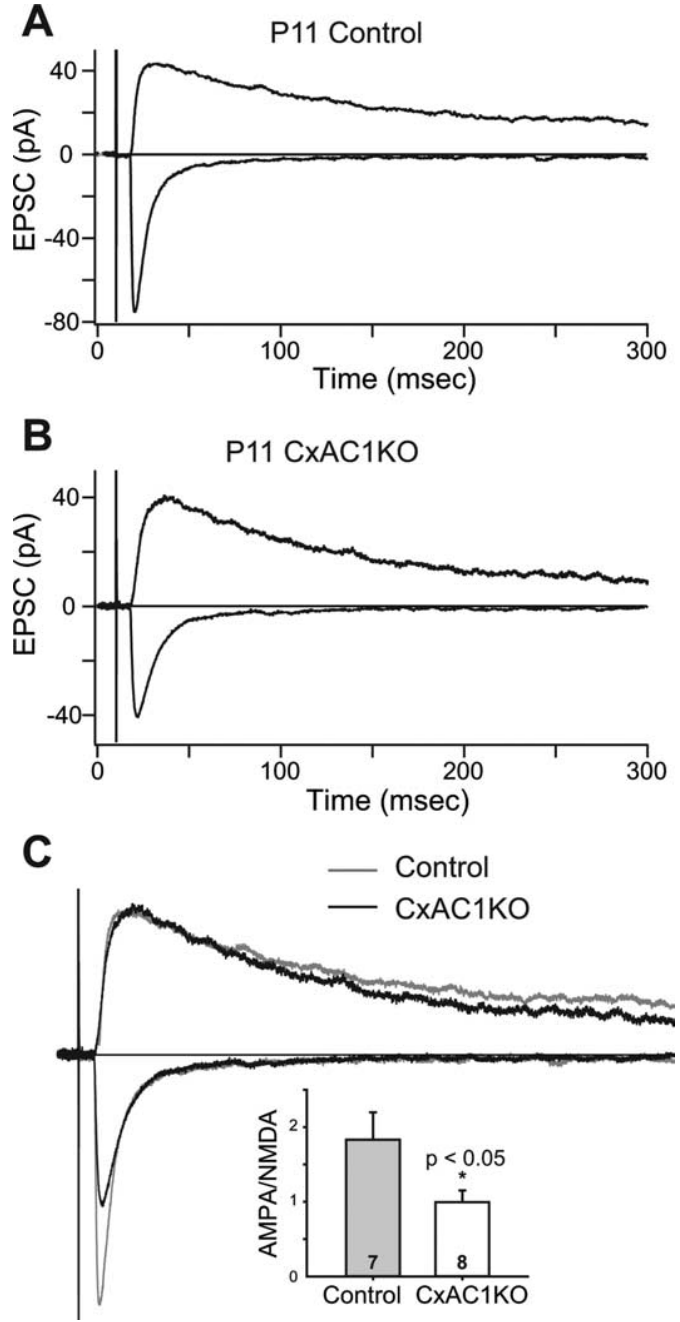

Figure 6. AMPA/NMDA current ratio is reduced in CXAC1KO mice. $A, B$, Sample whole-cell voltage-clamp measurements of AMPA receptor-mediated and NMDA receptor-mediated TC EPSCs in a P11 littermate control $(\boldsymbol{A})$, and P11 CXAC1KO ( $\boldsymbol{B})$ mouse. $\boldsymbol{C}$, Overlay of the responses in $\boldsymbol{A}$ and $\boldsymbol{B}$ scaled so that the NMDA receptor currents are the same amplitude. Note the AMPA receptor-mediated EPSC in CXAC1KO animal is small compared with the littermate control. Inset, Summary quantification of AMPA/NMDA current ratios of control $\left(\mathrm{AC}^{\text {flox/- }}{ }^{-}\right)$and CXAC1K0 mice at P9-P11. The AMPA/NMDA current ratio of CXAC1KO mice is significantly smaller than that of control mice $\left({ }^{*} p<0.05 ; t\right.$ test). Error bars indicate SEM.

\section{LTP is impaired in CxAC1KO mice during TC synapse development}

The trafficking of AMPA receptors into synapses is thought to control synaptic strength during map refinement (Crair and Malenka, 1995; Feldman et al., 1998; Lu et al., 2003; Inan et al., 2006). LTP at the TC synapse, which can only be induced during a critical period that ends around P7 (Crair and Malenka, 1995), is thought to depend on AMPA receptor insertion into TC synapses. Our previous work showed that LTP cannot be induced at brl TC synapses, which is consistent with the fewer functional AMPA receptors observed at these synapses. Therefore, the lower AMPA receptor response observed in $\mathrm{CxAC} 1 \mathrm{KO}$ mice might be associated with a defect in TC LTP. We examined this possibility using a standard LTP "pairing" protocol in TC slices from P4-P6 $\mathrm{CxAC1KO}$ and littermate control ( $\mathrm{AC}^{\text {flox/- }}$, Emx1-Cre; $\mathrm{ACl}^{+/-}, \mathrm{ACl}^{+/-}$, and $\mathrm{ACl}^{\text {flox/++}}$ ) mice (Fig. 8). All control groups showed a significant potentiation, whereas the $\mathrm{CxAC} 1 \mathrm{KO}$ mice did not $(p<0.05$ for control groups and $p=0.59$ for CxAC1KOs, paired $t$ test). We also found that the amount of potentiation (EPSC percentage change) was significantly lower in CxAC1KO mice $(4.0 \pm 2.4 \% ; n=8)$ compared with any of the control groups ( $\mathrm{ACl}^{\text {flox } /+}, 83.2 \pm 8.5 \%, n=3 ; \mathrm{ACl}^{+/-}, 49.2 \pm$ $12.9 \%, n=5$; Emx1-Cre; $\mathrm{ACl}^{+/-}, 65.4 \pm 26.2 \%, n=5$; $\mathrm{AC}^{\text {flox } /-}, 53.9 \pm 15.9 \%, n=8 ; p<0.05$, Student's $t$ test $)$, which are pooled together in Figure 8 (60.3 $\pm 9.0 \% ; p<0.01$, Student's $t$ test). This suggests that AC1 function in layer IV neurons is responsible for the normal functional development of TC synapses, and that the impaired LTP observed in $b r l$ mice is attributable at least in part to the absence of $\mathrm{ACl}$ function in cortical neurons.

\section{TC synaptic release efficacy is intact in CxAC1 KO mice}

We next examined whether CXAC1KO mice have normal presynaptic function at TC synapses. One estimate of presynaptic release is the short-term plasticity measured by comparing the responses to two closely spaced stimuli. This paired-pulse ratio (PPR), which is the amplitude of the second response relative to the first response, is indicative of the probability of release $(\mathrm{Pr})$ at a synapse (Zucker, 1973, 1989). PPRs $<1$, called paired-pulse depression (PPD), indicate that a synapse has a relatively high Pr. TC synapses are high Pr synapses showing PPD. brl TC synapses have higher PPRs, or lower Pr, than control TC synapses (Lu et al., 2006). To investigate whether the low $\mathrm{Pr}$ at $b r l \mathrm{TC}$ synapses is attributable to the lack of cortical $\mathrm{AC} 1$ function, we measured the NMDA receptor responses to paired stimuli at four different ISIs (Fig. 9). We found no difference in the PPRs of TC synapses of CxAC1KO mice compared with those of littermate control $\left(\mathrm{ACl}^{\text {flox/- }}\right)$ mice at any ISI (Fig. $\left.9 A, B\right)$, indicating no defect in neurotransmitter release efficacy (Fig. 9C) [for littermate controls $(n=8)$ and for CxAC1KOs $(n=8)$, respectively: $0.53 \pm$ 0.05 and $0.52 \pm 0.06, p=0.81, t$ test at ISI $=50 \mathrm{~ms} ; 0.55 \pm 0.04$ and $0.57 \pm 0.05, p=0.75, t$ test at ISI $=75 \mathrm{~ms} ; 0.60 \pm 0.08$ and $0.58 \pm 0.04, p=0.82, t$ test at ISI $=100 \mathrm{~ms} ; 0.65 \pm 0.05$ and $0.63 \pm 0.02, p=0.70, t$ test at ISI $=500 \mathrm{~ms}]$.

Another estimate of presynaptic release is obtained by measuring the rate of NMDA receptor current decay in the presence of the irreversible open channel blocker MK801. The rate at which the amplitude of NMDA receptor-mediated EPSCs are attenuated by MK801 during repetitive stimulation is directly related to Pr (Rosenmund et al., 1993). Since MK801 is an irreversible open channel blocker, more NMDA receptors will be permanently blocked, and the blockade rate will be faster in high Pr synapses compared to synapses with lower Pr. NMDA receptor currents from TC synapses in $\mathrm{brl}$ mice take longer to block in the presence of MK801 relative to control synapses, which is consistent with a reduced $\operatorname{Pr}$ (Lu et al., 2006). We measured the rate of NMDA receptor block at $\mathrm{CxAC1KO}$ and littermate control $\left(\mathrm{AC}^{\text {flox } /-}\right.$ ) TC synapses using MK801 and observed a similar blockade rate (Fig. 10A,B). The summary plot of the percentage block calculated by normalizing each sweep to the amplitude of the first sweep after resuming stimulation also showed no difference (Fig. 10C). Comparison of the weighted tau, calculated by fitting a double exponential curve to each cell showed no significant difference between $\mathrm{CxAC} 1 \mathrm{KOs}$ and their littermate controls (Fig. 10D) [9.68 \pm 1.04 sweeps for littermate controls $(n=8)$ and $9.37 \pm 1.41$ sweeps for CxAC1KOs $(n=8) ; p=0.86, t$ test $]$. These results all indicate that the lower neurotransmitter release efficacy observed at TC synapses in $\mathrm{brl} \mathrm{mice} \mathrm{is} \mathrm{not} \mathrm{attributable} \mathrm{to}$ lack of $\mathrm{AC} 1$ function in excitatory cortical neurons, but is consistent with a functional role of $\mathrm{AC} 1$ in presynaptic $\mathrm{TC}$ afferent terminals. 
A
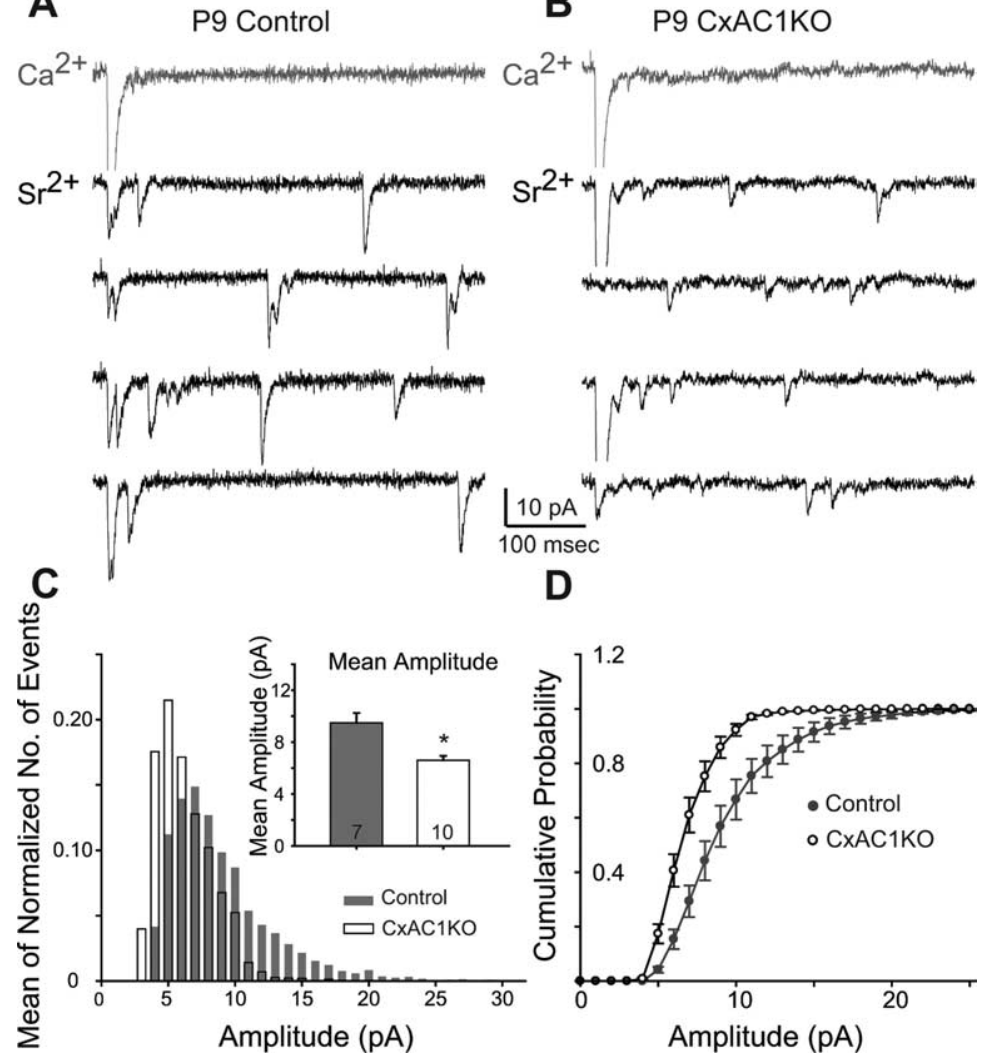

Figure 7. AMPA receptor mini-EPSCs are smaller at CXAC1KO TC synapses. $\boldsymbol{A}, \boldsymbol{B}$, Sample traces of evoked AMPA receptormediated current responses in $\mathrm{Ca}^{2+}$-ACSF (gray) and $\mathrm{Sr}^{2+}$-ACSF (black) from recordings in $\mathrm{P9}$ CXAC1KO $(\boldsymbol{B})$ and littermate control $\left(\mathrm{AC}^{\text {flox/- }}{ }^{-}\right)(\boldsymbol{A})$ neurons. In the presence of $\mathrm{Sr}^{2+}-\mathrm{ACSF}$, responses to evoked synchronous release is lower and quantal events (evoked mini-EPSCS) in response to asynchronous release appear. The amplitudes of these quantal events are smaller on average in CXAC1KO mice. C, Average frequency histogram of evoked mini-EPSCS. The CXAC1KO histogram (white bars) peaks at a smaller amplitude than littermate controls (gray bars), and large amplitude events are almost absent in CXAC1KO mice. Inset, Mean evoked mini-EPSC amplitude is significantly lower ( ${ }^{*} p<0.05, t$ test) for $\mathrm{XAC1KO}$ mice (white) with respect to littermate controls (gray). Error bars indicate SEM. D, The cumulative probability distribution in CXAC1KO animals (white) also shows a shift toward smaller amplitudes compared with littermate controls (gray).

\section{Discussion}

We generated $\mathrm{CxAC1KO}$ mice in which the AC1 gene is disrupted in the cortex but not in the thalamus or the brainstem. We found that these mice show a grossly normal barrel pattern, in contrast to global AC1 KO mice that lack any signature of cortical barrels. Whisker follicle lesion-induced critical period plasticity in the barrel cortex of $\mathrm{CxAC} 1 \mathrm{KO}$ mice was also similar to that of control mice. These results suggest that $\mathrm{AC} 1$ in cortical excitatory neurons is not necessary for the development of an overtly normal barrel map or lesion-induced plasticity. However, we found that cortical AC1 plays an important role in development of the asymmetric dendritic morphology typical of layer IV barrel neurons and in the emergence of a fully normal layer IV barrel cytoarchitecture. Our physiological analyses of TC synapses in CxAC1KO mice revealed that cortical AC1 is required for induction of LTP and for strengthening of TC synapses through an increase in AMPA receptor-mediated currents, but not for regulation of presynaptic release efficacy. Thus, CxAC1KO mice revealed specific roles for cortical AC1 in the morphological and physiological maturation of layer IV barrel neurons.

\section{How does postsynaptic AC1 regulate morphological and} physiological maturation of barrel neurons?

Adenylyl cyclases are a family of broadly expressed proteins that catalyze the conversion of ATP to CAMP when stimulated. AC1 is a neuron-specific and membrane-bound form of adenylyl cyclase that is sensitive to changes in cytosolic $\mathrm{Ca}^{2+}$ concentration (Wang and Storm, 2003; Ferguson and Storm, 2004). Activation of AC1 by $\mathrm{Ca}^{2+}$ occurs in neurons through NMDA receptors and/or voltage-gated $\mathrm{Ca}^{2+}$ channels (Kovalchuk et al., 2000; Bloodgood and Sabatini, 2007), leading to an increase in cAMP production, a second messenger whose primary target is PKA. The cAMP/ PKA signaling pathway has been implicated in a wide range of activity-dependent processes such as hippocampal and cerebellar synaptic plasticity in adulthood and developmental plasticity in the visual cortex (Storm et al., 1998; Villacres et al., 1998; Wong et al., 1999; Xia and Storm, 2005; Cui et al., 2007).

The location and position of the face map during the construction of barrels in the rodent somatosensory cortex is dictated by molecular gradients intrinsic to the neocortex (Grove and FukuchiShimogori, 2003; Sur and Rubenstein, 2005; Inan and Crair, 2007). However, patterning of layer IV neurons to form barrels within the somatotopic map is to a large extent guided by activity-dependent mechanisms. Our current understanding is that TC axons are the first neural elements in the cortex to form a peripheryrelated pattern and provide a template of the whisker-specific pattern to the presumptive barrel field (Erzurumlu and Jhaveri, 1990; Senft and Woolsey, 1991; Agmon et al., 1993). Layer IV neurons then form clusters (walls) around the discrete patches of TC axon arbors and orient their dendrites toward them. Studies of the phenotypes of several lines of mutant mice revealed that glutamatergic synaptic transmission, its modulation by serotonin (5-HT), and signaling pathways regulated by neuronal activity play a major role in development of the barrel cortex (Erzurumlu and Kind, 2001; Erzurumlu and Iwasato, 2006; Inan and Crair, 2007). The barrel cortex phenotype of CxAC1KO mice described here suggests that cortical AC1 function plays a critical role in the preference for layer IV spiny stellate neurons to orient their dendrites toward TC axon arbors and form normal layer IV barrels.

Synaptic plasticity at developing somatosensory TC synapses is NMDA receptor and $\mathrm{Ca}^{2+}$-dependent, and the maturation of TC synapses involves an increase in AMPA receptor-mediated currents (Crair and Malenka, 1995; Feldman et al., 1998). Synaptic maturation is thought to occur through LTP-like mechanisms that regulate the trafficking of AMPA receptors into the synapse via PKA-dependent phosphorylation of AMPA receptors (Crair and Malenka, 1995; Lu et al., 2003; Inan et al., 2006). Mice with a global KO of PKARII $\beta$ have deficits in synaptic plasticity and TC synapse maturation (Inan et al., 2006). Immunoelectron microscopic and biochemical evidence suggests that PKARII $\beta$ is located and functions primarily on the postsynaptic side of developing TC synapses (Inan et al., 2006; Watson et al., 2006). In this study, we showed that $\mathrm{CXAC1KO}$ mice have physiological phe- 
Table 1. Summary of barrel system phenotypes in $\mathrm{AC}^{-/-}$(global knock-out or brl mice) and CxAC1KO mice

\begin{tabular}{|c|c|c|c|c|c|}
\hline & \multicolumn{3}{|l|}{ Morphology } & \multicolumn{2}{|c|}{ TC physiology } \\
\hline & Barrelettes (brainstem) & Barreloids (thalamus) & Barrels (cortex) & Presynaptic & Postsynaptic \\
\hline $\mathrm{AC} 1^{-1-}$ & Normal & Partial & Absent & Impaired & Impaired \\
\hline CXAC1KO & Normal & Normal & Grossly normal & Normal & Impaired \\
\hline
\end{tabular}

In AC1 ${ }^{-1-}$ (global knock-out or br/ mice), whisker-related patterning is completely disrupted in the S1 barrel cortex, partially disrupted in the VB thalamus, and normal in the brainstem. Both presynaptic and postsynaptic measures of TC synapse function are also disrupted in $\mathrm{AC1}{ }^{-1-}$ mice. In (XAC1KO mice, TC axon clustering and layer IV barrel morphology is grossly normal, although quantitative measures of layer IV barrel cytoarchitecture and barrel neuron morphology reveal small deficits. At the same time, thalamic barreloids and brainstem barrelettes are normal in CXAC1KO mice. Physiologically, the TC synapse has normal presynaptic but disrupted postsynaptic function in CXAC1KO mice.

notypes similar to those observed in PKA$\mathrm{RII} \beta \mathrm{KO}$ mice. This suggests that postsynaptic AC1/cAMP/PKA signaling plays an important role in TC synapse maturation. Morphologically, layer IV neurons in the barrel cortex of both cortex-specific $\mathrm{KO}$ mice of NMDA receptor NR1 subunit (Datwani et al., 2002a) and PKARII $\beta$ KO mice (Inan et al., 2006) show reduced dendritic asymmetry, similar to that of CxAC1KO mice. Therefore, it is likely that by linking NMDA receptor-mediated $\mathrm{Ca}^{2+}$ influx and PKA activation, cortical AC1 plays a role in postsynaptic physiological maturation of TC synapses, which underlies the emergence of asymmetric dendritic orientation in barrel neurons, a key feature of the morphological maturation of barrels.

\section{Where and how does AC1 influence barrel map patterning?}

We did not detect a gross impairment in cortical barrel patterning in $\mathrm{CxAC} 1 \mathrm{KO}$ mice. Although quantitative analyses detected subtle differences in layer IV neuron barrel cytoarchitecture assayed with postsynaptic markers in $\mathrm{CxAC} 1 \mathrm{KO}$ mice, it is clear that the absence of AC1 in excitatory neurons of the cortex is not sufficient to reproduce the severe barrel map phenotype observed in global $\mathrm{AC1} \mathrm{KO}$ and brl mice (Welker et al., 1996) (Figs. 1C-F, $3)$. Because the AC1 gene is highly expressed throughout the somatosensory system during early postnatal development (Matsuoka et al., 1997; Nicol et al., 2005), the lack of AC1 function in the thalamus and/or brainstem of $b r l$ mice, which is unaffected in CXAC1KO mice, may contribute to the complete disruption of the cortical barrel pattern in brl mice.

One route for the subcortical action of $\mathrm{ACl}$ may be in $\mathrm{TC}$ afferents, because $b r l$ mice have impaired neurotransmitter release efficacy ( $\mathrm{Lu}$ et al., 2006), which was not observed in CxAC1KO mice (Figs. 9, 10). This physiological impairment may be mediated by RIMs, active zone proteins that modulate neurotransmitter release and are phosphorylated by PKA downstream of AC1 ( $\mathrm{Lu}$ et al., 2006). Consistent with this, $\operatorname{Rim} 1 \alpha \mathrm{KO}$ mice have a mild barrel phenotype and presynaptic functional impairments at TC synapses similar to those observed in $\mathrm{brl}$ mice (Lu et al., 2006). A presynaptic role for AC1 in sensory map refinement is also suggested by in vitro evidence in the visual system. In $\mathrm{brl}$ mice, the segregation of ipsilateral and contralateral retinotectal

C

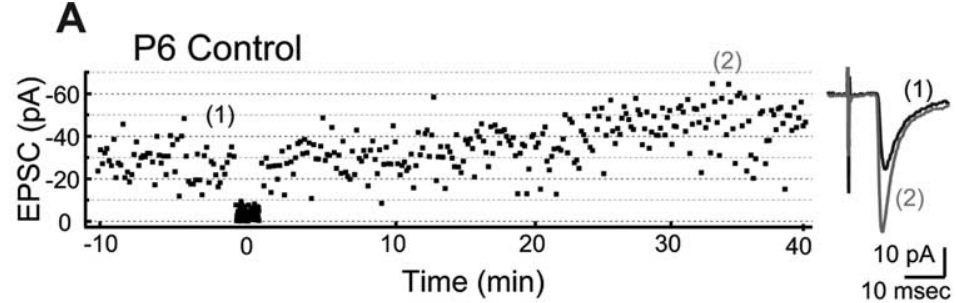

\section{P6 CXAC1KO}

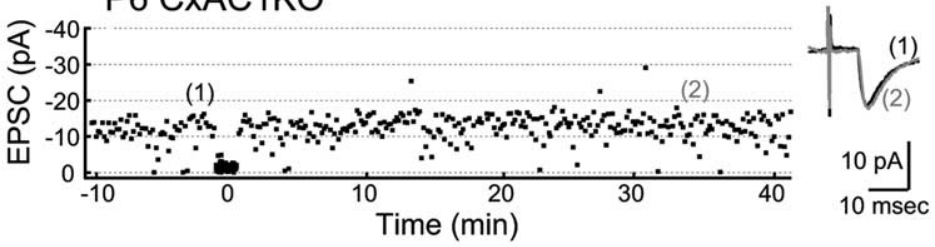

D
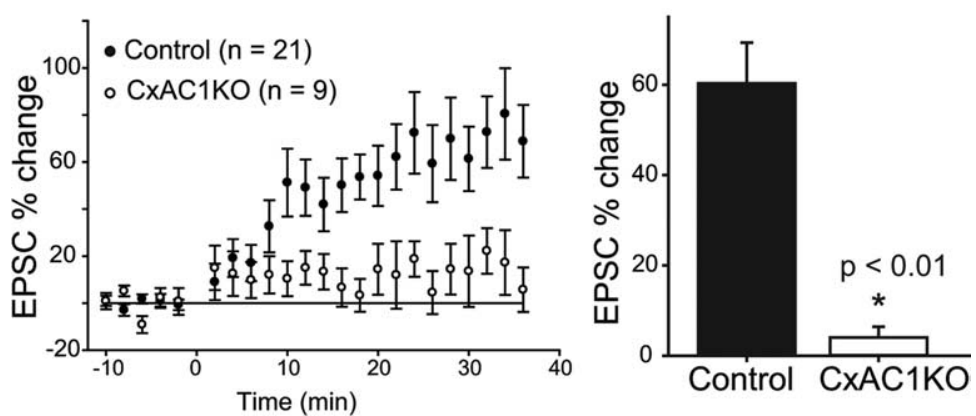

Figure 8. LTP is defective at CXAC1KO TC synapses. $\boldsymbol{A}, \boldsymbol{B}$, Example whole-cell voltage-clamp recordings from P6 littermate control $\left(A C 1^{\text {flox/- }}\right)(\boldsymbol{A})$ and P6CXAC1KO $(\boldsymbol{B})$ neurons show that TC AMPA response in control but not CXAC1KO layer IV neurons can be potentiated using an LTP "pairing" protocol. Traces on the right (average of 20 sweeps) from before (1) and 35 min after (2) pairing show significant potentiation in control but not in CXAC1KO neurons. C, Summary graph of pairing experiments showing the EPSC percentage change for CXAC1K0 mice (open circles) and controls ( $\mathrm{AC} 1^{\text {flox } /-}$, Emx1-Cre; $\mathrm{AC} 1^{+/-}, \mathrm{AC} 1^{+/-}$, and $A C{ }^{f l o x /+}$ ) (filled circles). Control TC synapses reveal obvious potentiation, whereas CXAC1KOs cannot potentiate. Error bars control and CXAC1KO TC synapses. CXAC1KO TC synapses show almost no potentiation and their EPSC percentage change is significantly lower $\left({ }^{*} p<0.01\right.$, Student's $t$ test $)$ than that of control mice.

and retinogeniculate axons is impaired (Ravary et al., 2003; Plas et al., 2004; Nicol et al., 2006b). In vitro coculture assays using retinal and tectal explants from wild-type and $b r l$ mice show that wild-type retinal axons correctly target in the $b r l$ tectum but $b r l$ retinal axons fail to establish regional selectivity and refinement in the wild-type tectum, suggesting a presynaptic role for $\mathrm{AC} 1$ in sensory map refinement (Nicol et al., 2006a).

In addition to the complete disruption of cortical barrels, thalamic barreloid formation is also modestly impaired in $\mathrm{ACl}^{-1-}$ (global $\mathrm{ACl} \mathrm{KO}$ and $b r l$ ) mice. AC1 in thalamic or brainstem neurons may play a direct role in the formation of VB thalamic barreloids. Although brainstem barrelettes are intact in $\mathrm{ACl}^{-1-}$ mice, it is possible that functional input from brainstem axons projecting to VB thalamic neurons is impaired. The progressive 
A

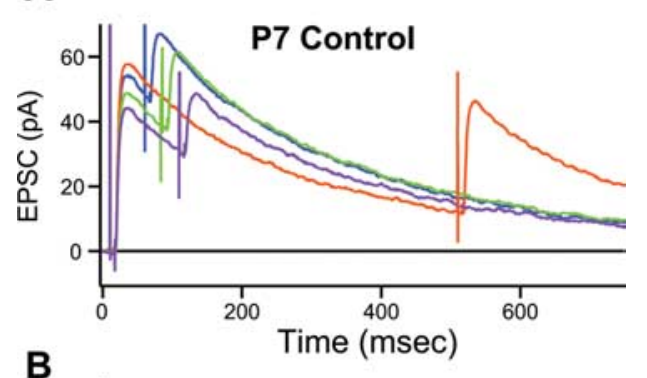

B

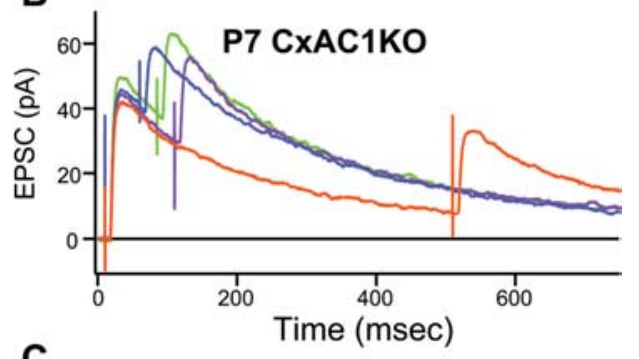

C

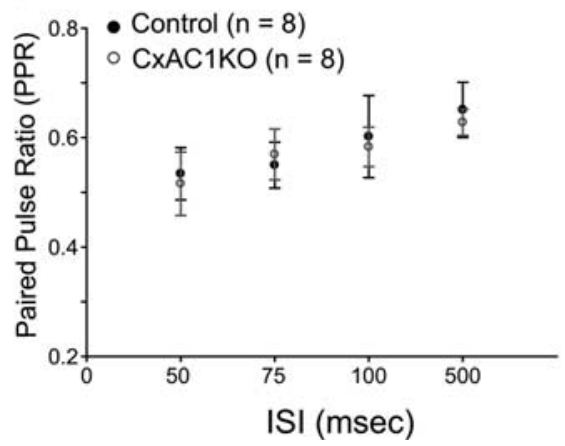

Figure 9. PPR at CXAC1KO TC synapses is similar to littermate controls. $\boldsymbol{A}, \boldsymbol{B}$, Average example EPSC responses of a P7 (XAC1KO $(B)$ and a P7 littermate control ( $\left.A C 1^{\text {flox/ }}{ }^{-}\right)(A)$ cell to paired stimuli at ISIs $50 \mathrm{~ms}$ (blue), $75 \mathrm{~ms}$ (green), $100 \mathrm{~ms}$ (purple), and $500 \mathrm{~ms}$ (orange) reveal similar PPRs. C, Summary plot for average PPRs at ISIs at 50,75, 100, and 500 ms are not different between (XAC1KO (open circles) and littermate controls (black circles) at P5-P7, suggesting that $\operatorname{Pr}$ at XAC1KO TC synapses is not defective. Error bars indicate SEM.

deterioration in the whisker pattern evident when ascending the trigeminal pathway from brainstem through thalamus to cortex in $\mathrm{ACl}^{-/-}$mice may indicate a cumulative role for $\mathrm{ACl}$ in the transfer of information about the whisker pattern through the trigeminal system (for a summary of morphological and physiological phenotypes in $\mathrm{ACl}^{-/-}$and $\mathrm{CxAClKO}$ mice, see Table 1).

It is intriguing that the extent of lesion-induced morphological plasticity and the duration of the critical period in CxAC1KO mice are indistinguishable from those of control mice. We previously demonstrated that CxNR1KO mice, in which NMDA receptor function is genetically impaired only in cortical excitatory neurons, showed normal lesion-induced TC axonal plasticity (Datwani et al., 2002b), and mutant mice for PKARII $\beta$, which is expressed in layer IV cortical neurons but not TC axon terminals, showed normal lesion-induced plasticity (Inan et al., 2006). Furthermore, parachlorophenylalanine-treated MAOA knock-out mice, in which the emergence of barrel patterning, but not barreloid and barrelette patterning, is delayed, show no delay in the closure of the lesion-induced plasticity period (Rebsam et al., 2005). Thus, it is likely that lesion-induced morphological plasticity is regulated at the subcortical level.

An alternative explanation for the relatively mild morphological phenotype and normal lesion-induced morphological plas- ticity in $\mathrm{CxAC} 1 \mathrm{KO}$ mice could be the persistence of $\mathrm{AC} 1$ expression in cortical interneurons of CxAC1KO mice, because Cremediated gene disruption induced by Emx1-Cre mice is restricted to excitatory neurons in the cortex (Iwasato et al., 2000, 2004). Inhibitory synaptic transmission mediated by interneurons has emerged as an essential component for shaping aspects of the development and plasticity of cortical networks (Hensch and Stryker, 2004; Foeller et al., 2005; Gabernet et al., 2005). However, inhibitory neurons make up only $15 \%$ of the neuronal population in layer IV of cortex (Lin et al., 1985). Although inhibitory synaptic circuitry develops after the critical period for TC synapse maturation and barrel map formation (Daw et al., 2007), we cannot rule out a role for inhibitory interneurons in anatomical map development. To clarify these various possibilities, the role of $\mathrm{ACl}$ in the thalamus, brainstem, and cortical inhibitory neurons needs to be explicitly determined.

\section{References}

Abdel-Majid RM, Leong WL, Schalkwyk LC, Smallman DS, Wong ST, Storm DR, Fine A, Dobson MJ, Guernsey DL, Neumann PE (1998) Loss of adenylyl cyclase I activity disrupts patterning of mouse somatosensory cortex. Nat Genet 19:289-291.

Agmon A, Yang LT, O’Dowd DK, Jones EG (1993) Organized growth of thalamocortical axons from the deep tier of terminations into layer IV of developing mouse barrel cortex. J Neurosci 13:5365-5382.

Beaulieu C (1993) Numerical data on neocortical neurons in adult rat, with special reference to the GABA population. Brain Res 609:284-292.

Bloodgood BL, Sabatini BL (2007) $\mathrm{Ca}^{2+}$ signaling in dendritic spines. Curr Opin Neurobiol 17:345-351.

Chan CH, Godinho LN, Thomaidou D, Tan SS, Gulisano M, Parnavelas JG (2001) Emx1 is a marker for pyramidal neurons of the cerebral cortex. Cereb Cortex 11:1191-1198.

Crair MC, Malenka RC (1995) A critical period for long-term potentiation at thalamocortical synapses. Nature 375:325-328.

Cui W, Smith A, Darby-King A, Harley CW, McLean JH (2007) A temporalspecific and transient cAMP increase characterizes odorant classical conditioning. Learn Mem 14:126-133.

Datwani A, Iwasato T, Itohara S, Erzurumlu RS (2002a) NMDA receptordependent pattern transfer from afferents to postsynaptic cells and dendritic differentiation in the barrel cortex. Mol Cell Neurosci 21:477-492.

Datwani A, Iwasato T, Itohara S, Erzurumlu RS (2002b) Lesion-induced thalamocortical axonal plasticity in the S1 cortex is independent of NMDA receptor function in excitatory cortical neurons. J Neurosci 22:9171-9175.

Daw MI, Ashby MC, Isaac JT (2007) Coordinated developmental recruitment of latent fast spiking interneurons in layer IV barrel cortex. Nat Neurosci 10:453-461.

Durham D, Woolsey TA (1984) Effects of neonatal whisker lesions on mouse central trigeminal pathways. J Comp Neurol 223:424-447.

Erzurumlu RS, Iwasato T (2006) Patterning of the somatosensory maps with NMDA receptors. In: Development and plasticity in sensory thalamus and cortex (Erzurumlu RS, Guido W, Molnár Z, eds), pp 158-182. New York: Springer.

Erzurumlu RS, Jhaveri S (1990) Thalamic axons confer a blueprint of the sensory periphery onto the developing rat somatosensory cortex. Brain Res Dev Brain Res 56:229-234.

Erzurumlu RS, Kind PC (2001) Neural activity: sculptor of "barrels" in the neocortex. Trends Neurosci 24:589-595.

Feldman DE, Nicoll RA, Malenka RC, Isaac JT (1998) Long-term depression at thalamocortical synapses in developing rat somatosensory cortex. Neuron 21:347-357.

Ferguson GD, Storm DR (2004) Why calcium-stimulated adenylyl cyclases? Physiology (Bethesda) 19:271-276.

Foeller E, Celikel T, Feldman DE (2005) Inhibitory sharpening of receptive fields contributes to whisker map plasticity in rat somatosensory cortex. J Neurophysiol 94:4387-4400.

Gabernet L, Jadhav SP, Feldman DE, Carandini M, Scanziani M (2005) Somatosensory integration controlled by dynamic thalamocortical feedforward inhibition. Neuron 48:315-327.

Gorski JA, Talley T, Qiu M, Puelles L, Rubenstein JL, Jones KR (2002) Cor- 
tical excitatory neurons and glia, but not GABAergic neurons, are produced in the Emxl-expressing lineage. J Neurosci 22:6309-6314.

Grove EA, Fukuchi-Shimogori T (2003) Generating the cerebral cortical area map. Annu Rev Neurosci 26:355-380.

Hensch TK, Stryker MP (2004) Columnar architecture sculpted by GABA circuits in developing cat visual cortex. Science 303:1678-1681.

Inan M, Crair MC (2007) Development of cortical maps: perspectives from the barrel cortex. Neuroscientist 13:49-61.

Inan M, Lu HC, Albright MJ, She WC, Crair MC (2006) Barrel map development relies on protein kinase A regulatory subunit II beta-mediated cAMP signaling. J Neurosci 26:4338-4349.

Iwasato T, Erzurumlu RS, Huerta PT, Chen DF, Sasaoka T, Ulupinar E, Tonegawa S (1997) NMDA receptor-dependent refinement of somatotopic maps. Neuron 19:1201-1210.

Iwasato T, Datwani A, Wolf AM, Nishiyama H, Taguchi Y, Tonegawa S, Knopfel T, Erzurumlu RS, Itohara S (2000) Cortex-restricted disruption of NMDAR1 impairs neuronal patterns in the barrel cortex. Nature 406:726-731.

Iwasato T, Nomura R, Ando R, Ikeda T, Tanaka M, Itohara S (2004) Dorsal telencephalonspecific expression of Cre recombinase in PAC transgenic mice. Genesis 38:130-138.

Iwasato T, Katoh H, Nishimaru H, Ishikawa Y, Inoue $\mathrm{H}$, Saito YM, Ando R, Iwama M, Takahashi R, Negishi M, Itohara S (2007) RacGAP alpha-chimerin regulates motor-circuit formation as a key mediator of EphrinB3/ EphA4 forward signaling. Cell 130:742-753.

Kovalchuk Y, Eilers J, Lisman J, Konnerth A (2000) NMDA receptor-mediated subthreshold $\mathrm{Ca}^{2+}$ signals in spines of hippocampal neurons. J Neurosci 20:1791-1799.

Lebrand C, Cases O, Wehrle R, Blakely RD, Edwards RH, Gaspar P (1998) Transient developmental expression of monoamine transporters in the rodent forebrain. J Comp Neurol 401:506-524.

Lin CS, Lu SM, Schmechel DE (1985) Glutamic acid decarboxylase immunoreactivity in layer IV of barrel cortex of rat and mouse. J Neurosci 5:1934-1939.

Lu HC, Gonzalez E, Crair MC (2001) Barrel cortex critical period plasticity is independent of changes in NMDA receptor subunit composition. Neuron 32:619-634.

Lu HC, She WC, Plas DT, Neumann PE, Janz R, Crair MC (2003) Adenylyl cyclase I regulates AMPA receptor trafficking during mouse cortical "barrel" map development. Nat Neurosci 6:939-947.

Lu HC, Butts DA, Kaeser PS, She WC, Janz R, Crair MC (2006) Role of efficient neurotransmitter release in barrel map development. J Neurosci 26:2692-2703.

Malinow R, Malenka RC (2002) AMPA receptor trafficking and synaptic plasticity. Annu Rev Neurosci 25:103-126.

Matsuoka I, Suzuki Y, Defer N, Nakanishi H, Hanoune J (1997) Differential expression of type I, II, and V adenylyl cyclase gene in the postnatal developing rat brain. J Neurochem 68:498-506.

Nicol X, Muzerelle A, Bachy I, Ravary A, Gaspar P (2005) Spatiotemporal localization of the calcium-stimulated adenylate cyclases, AC1 and AC8, during mouse brain development. J Comp Neurol 486:281-294.

Nicol X, Muzerelle A, Rio JP, Metin C, Gaspar P (2006a) Requirement of adenylate cyclase 1 for the ephrin-A5-dependent retraction of exuberant retinal axons. J Neurosci 26:862-872.

Nicol X, Bennis M, Ishikawa Y, Chan GC, Reperant J, Storm DR, Gaspar P (2006b) Role of the calcium modulated cyclases in the development of the retinal projections. Eur J Neurosci 24:3401-3414.
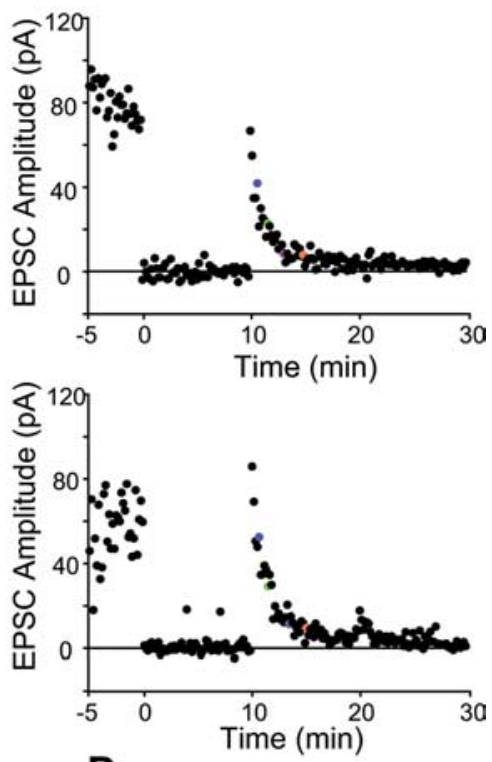

D

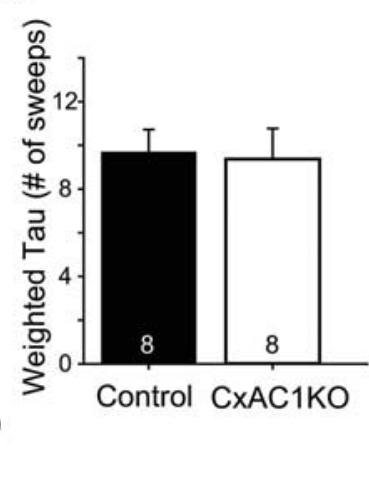

Sweep Number

Figure 10. СХАС1KO TC synapses exhibit no difference in Pr. $A, B$, Sample traces of a P6 CXAC1KO (B) and a P7 littermate control (A) taken at progressively later times after MK801 wash and the corresponding experiments with the NMDA receptor probability of release. Color of the sample traces $(\boldsymbol{A}, \boldsymbol{B})$ corresponds to the points colored on the amplitude plot indicate SEM. D, Weighted time constants (tau) measured by fitting a double-exponential curve to the NMDA receptor amplitude decay over time are not different between genotypes.

Plas DT, Visel A, Gonzalez E, She WC, Crair MC (2004) Adenylate cyclase 1 dependent refinement of retinotopic maps in the mouse. Vision Res 44:3357-3364.

Ravary A, Muzerelle A, Herve D, Pascoli V, Ba-Charvet KN, Girault JA, Welker E, Gaspar P (2003) Adenylate cyclase 1 as a key actor in the refinement of retinal projection maps. J Neurosci 23:2228-2238.

Rebsam A, Seif I, Gaspar P (2002) Refinement of thalamocortical arbors and emergence of barrel domains in the primary somatosensory cortex: a study of normal and monoamine oxidase a knock-out mice. J Neurosci 22:8541-8552.

Rebsam A, Seif I, Gaspar P (2005) Dissociating barrel development and lesion-induced plasticity in the mouse somatosensory cortex. J Neurosci 25:706-710.

Rosenmund C, Clements JD, Westbrook GL (1993) Nonuniform probability of glutamate release at a hippocampal synapse. Science 262:754-757.

Schlaggar BL, Fox K, O’Leary DD (1993) Postsynaptic control of plasticity in developing somatosensory cortex. Nature 364:623-626.

Senft SL, Woolsey TA (1991) Growth of thalamic afferents into mouse barrel cortex. Cereb Cortex 1:308-335.

Storm DR, Hansel C, Hacker B, Parent A, Linden DJ (1998) Impaired cerebellar long-term potentiation in type I adenylyl cyclase mutant mice. Neuron 20:1199-1210. 
Strominger RN, Woolsey TA (1987) Templates for locating the whisker area in fresh flattened mouse and rat cortex. J Neurosci Methods 22:113-118.

Sur M, Rubenstein JL (2005) Patterning and plasticity of the cerebral cortex. Science 310:805-810.

Van der Loos H, Woolsey TA (1973) Somatosensory cortex: structural alterations following early injury to sense organs. Science 179:395-398.

Villacres EC, Wong ST, Chavkin C, Storm DR (1998) Type I adenylyl cyclase mutant mice have impaired mossy fiber long-term potentiation. J Neurosci 18:3186-3194.

Wang H, Storm DR (2003) Calmodulin-regulated adenylyl cyclases: crosstalk and plasticity in the central nervous system. Mol Pharmacol 63:463-468.

Watson RF, Abdel-Majid RM, Barnett MW, Willis BS, Katsnelson A, Gillingwater TH, McKnight GS, Kind PC, Neumann PE (2006) Involvement of protein kinase A in patterning of the mouse somatosensory cortex. J Neurosci 26:5393-5401.

Welker E, Armstrong-James M, Bronchti G, Ourednik W, GheorghitaBaechler F, Dubois R, Guernsey DL, Van der Loos H, Neumann PE (1996) Altered sensory processing in the somatosensory cortex of the mouse mutant barrelless. Science 271:1864-1867.
Wong ST, Athos J, Figueroa XA, Pineda VV, Schaefer ML, Chavkin CC, Muglia LJ, Storm DR (1999) Calcium-stimulated adenylyl cyclase activity is critical for hippocampus-dependent long-term memory and late phase LTP. Neuron 23:787-798.

Wong-Riley MT, Merzenich MM, Leake PA (1978) Changes in endogenous enzymatic reactivity to DAB induced by neuronal inactivity. Brain Res 141:185-192.

Woolsey TA, Van der Loos H (1970) The structural organization of layer IV in the somatosensory region (SI) of mouse cerebral cortex. The description of a cortical field composed of discrete cytoarchitectonic units. Brain Res 17:205-242.

Woolsey TA, Wann JR (1976) Areal changes in mouse cortical barrels following vibrissal damage at different postnatal ages. J Comp Neurol 170:53-66.

Xia Z, Storm DR (2005) The role of calmodulin as a signal integrator for synaptic plasticity. Nat Rev Neurosci 6:267-276.

Xu-Friedman MA, Regehr WG (1999) Presynaptic strontium dynamics and synaptic transmission. Biophys J 76:2029-2042.

Zucker RS (1973) Changes in the statistics of transmitter release during facilitation. J Physiol (Lond) 229:787-810.

Zucker RS (1989) Short-term synaptic plasticity. Annu Rev Neurosci 12:13-31. 